\title{
Comprehensive 5P framework for active aging using the ecological approach: an iterative systematic review
}

\author{
Azadeh Lak ${ }^{1 *}$ (D), Parichehr Rashidghalam', Phyo K. Myint ${ }^{2}$ and Hamid R. Baradaran 3,4
}

\begin{abstract}
Background: "Active aging" is an inclusive term and has been defined from a variety of aspects in different domains throughout the literature. The aim of this review was to identify those aspects that play significant roles in building this concept using an ecological approach.

Methods: In this study, seven online databases, including JSTOR, Pub-Med, Web of Science, Google Scholar, ProQuest, EBSCO, and Scopus, were searched from 2002 to 2018 for both qualitative and quantitative articles published in English. Two reviewers independently found the related articles using the search terms "active aging" and "built environment" and included both "ageing" and "aging".

Results: Of 1500 records which passed the screening stage, 92 were eligible for inclusion in the review. A total of 15 subthemes were derived: (1) personal characteristics, (2) behavioral attitude, (3) land use, (4) access, (5) physical form, (6) cityscape/city image, (7) public open spaces, (8) housing, (9) social environment, (10) cultural Environment, (11) economic environment, (12) good governance, (13) physical health, (14) mental health, and (15) social health. Ecological themes of active aging can be defined as the 5P model: person, processes, place, prime, and policymaking.

Conclusions: The results of this study can shed light on different aspects of active aging. Also, the results emphasized the significance of the multidimensional nature of active aging, micro (person), meso (process), and macro systems (place and policymaking), based on health (prime) environments. Moreover, the results were based on the relationships between the person and the environment at the individual, interpersonal, and environmental levels, which can be used to conduct future studies and develop policies on aging populations.
\end{abstract}

Keywords: Active aging, Integrative systematic review, Ecological model

\section{Background}

Creating positive aspects of aging life is an important factor in achieving health expectancy. In societies with a growing elderly population, great attention should be paid to the participation of the elderly in their own well-being and that of their families. According to the UN (2015), the proportion of older people $\geq 65$ years will skyrocket from 901 million (12.3\%) in 2015 to 1.4 billion (16.5\%) in 2030 (56\% increase). Active aging is referred as aging well [1], and according to WHO (2002), the elderly will be able to sustain health and well-being if they increase their participation in

\footnotetext{
*Correspondence: A_Lak@sbu.ac.ir

${ }^{1}$ Faculty of Architecture and Urban Planning, Shahid Beheshti University,

Tehran 1983963113, Iran

Full list of author information is available at the end of the article
}

daily activities. WHO has also described the goal of active aging as the process of optimizing opportunities for health, participation, and security to enhance the quality of life as people age, while noting that these policies and programs should be based on the rights, needs, preferences, and capacities of older people [2].

The societies which aim to provide opportunities for older people to take part in national schemes, including social security schemes, environmental and urban planning, health services, civil society, and legislation, are likely to reach the goal of active aging. Active Aging Index is the means to rank different countries based on their status in such societal measures as the participation of the elderly in the workforce or life expectancy [3]. This is perhaps why WHO (2002) does not interpret active aging as a highly 
standard quality of life for a group of people, because this term is not considered as a phenotypic description of an individual or individuals.

However, the term active aging has been used to refer to different aspects in recent years [3]. For instance, several researchers classified and offered a definition of the active aging phenotype according to WHO: good functional ability and fitness; continued involvement in one's family and/ or peer group; maintenance of positive subjective wellbeing; a good physical, social, and mental health; and engagement with community throughout the aging process. These factors have been proposed as key aspects that describe an active aging phenotype $[4,5]$.

There are several ignored ecological aspects that are considered to be conducive to the concept of maintaining active aging communities. Therefore, this study aimed to explore the topic with a new approach to analyze the determinants of active aging through a narrative review. The ecological approach considers aging as an interplay between an individual's functional age and adaptation with the physical and social environment [6], which links aging to the respective concepts of urban design and service planning for disability and aging. Such approaches are wide-ranging, including the creation of healthy cities, livable communities, walkable communities, universal design, and accessibility [7, 8]. Although all these notions aim for different goals, they commonly provide older people with essential elements for health: (eg, accessible and affordable health and healthcare services, opportunities to stay active, etc.), social security (eg, home and pedestrian safety, neighborhood safety [9], community safety, transportation safety, financial security, affordable housing, and services, etc.), which allow active social participation and engagement activities (eg, through accessible public transportation, information services, recreational programs, social connections, volunteer opportunities, and places to worship, etc.) [10].

Thus, cities and urban environments should focus on their local conditions aiming for the health and comfort of the older people while acknowledging their impact. Cities, enjoying their long-time experience of working with local communities and local problems, are also in the right position to satisfy the needs of aging adults [11-13]. To this end, there is a need to identify the factors that contribute to different aspects of health in older people while understanding the elements that could prevent them from taking part in daily activities. Also, mobility and independence, which may lead to a lower level of assisted living conditions and dependency, are of significant importance [12-14].

A review provided an analysis of research evidence according to the proposed questions with a specific systematic method to determine, select, and appraise the related primary research [15]. Therefore, in this narrative review, the aging population was defined as those who are 60 years or over and seek to respond to cultural and national differences. In this study, it was aimed to offer an understanding of what components of the activity of the elderly, built for the elderly in the environment based on the ecological perspective, can provide the opportunity for further studies on active aging.

\section{Methods}

This was a narrative review of a series of studies on the topic of active aging [16]. This led the authors to decide on the classification of the experiences, social contexts, and views on active aging as a common theme based on the ecological approach of the related articles [17-19]. Therefore, theoretical and empirical studies were also analyzed to merge (synthesize) the data as a narrative review [20]. In line with the existing literature, the aims of the study were as follow: defining concepts, reviewing evidence, analyzing the methodological issues of the concept, and reviewing the theories [21].

\section{Search strategy and study selection}

An iterative approach was used in this study as a narrative review and allowed the authors to revise the inclusion and exclusion criteria (Table 1), search strategy (Fig. 1), and the main research questions after considering the evidence [20,22]. Problem identification stage clarified that although aging is a natural part of life, active aging is a positive concept compared to inactive aging (living in a nursing home). Therefore, studying active aging also includes investigating the aspects and characteristics of the aging potential and offering methods to improve the understanding of aging [23]. The main question of this research was "What are the effective attributes in developing the notion of active aging according to the ecological model?"

The literature search was done as the second stage of narrative review from August to October 2018 and updated again in January 2019. A total of 7 online databases (Pub-Med, Web of Science, ISI, Google Scholar, ProQuest, EBSCO, and Scopus) were searched. The keywords used were "active aging" and "built environment"

Table 1 Inclusion/Exclusion Criteria for Selecting the Articles for This Review

\begin{tabular}{ll}
\hline Inclusion & Exclusion \\
\hline - Sampling of community-dwelling older adults aged 60 years or older; assessing health-related issues & - Participants were not only from \\
or component behaviors of the World Health Organization's active aging concept; studies that considered & residential environments \\
the environment or related concept as a potential correlate of health or activity; and studies that adopted & - Not limited to residential properties \\
qualitative, quantitative, or mixed methods & only \\
- Application of a stated theory or conceptual framework & \\
- Papers with English abstract or summary &
\end{tabular}




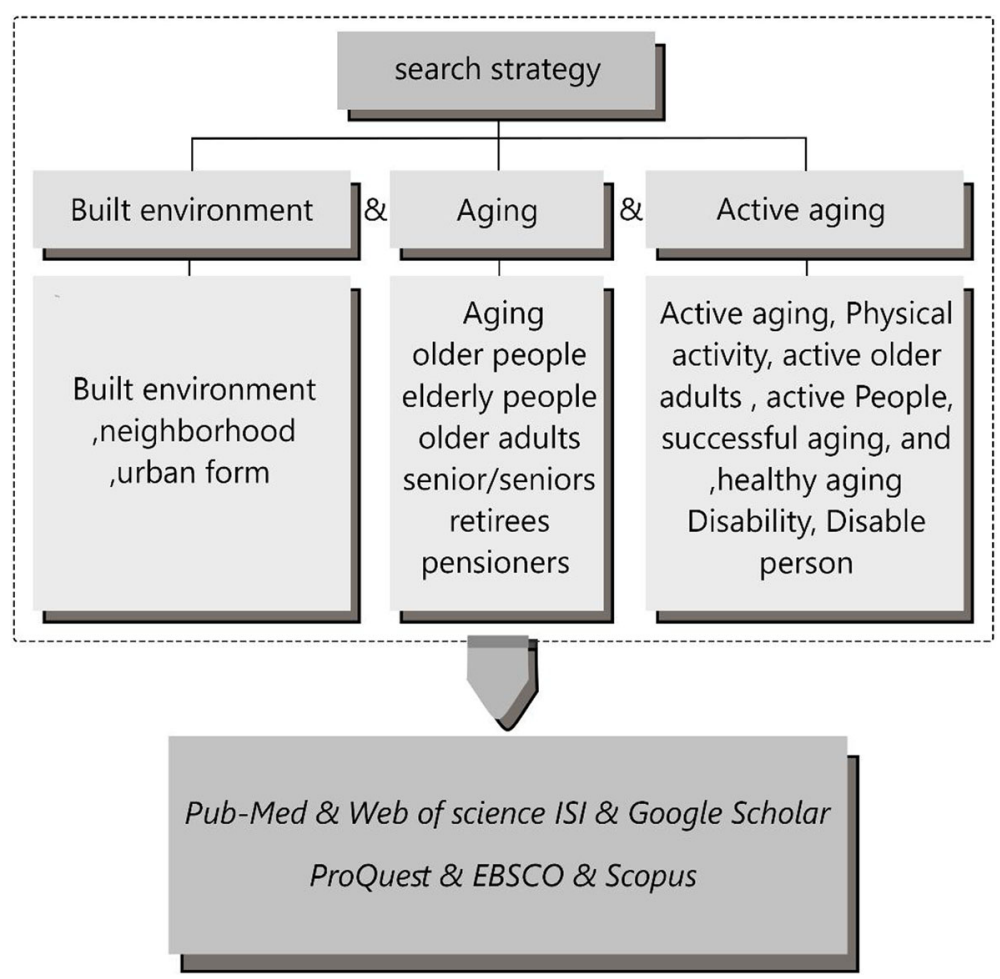

Fig. 1 Search Strategy Summary With Keywords

and included "ageing" and "aging" "senior"/"seniors", "retirees", and "pensioners".

To provide an inclusive search strategy, a common review strategy of building blocks was applied and search items were categorized into concepts and later expanded with the synonyms through Boolean operators [20]. Berry Picking, which is commonly applied in the iterative search and allows the search strategy to evolve from the information obtained throughout the review process, was also used [24, 25]. Whenever a piece of new evidence was discovered, this review approach allowed the modification of the strategy based on the new evidence. In addition, the drop a concept searching technique allowed the stacking of terms approach to be used by firstly combining all term/concepts of the review and then removing the least relevant concepts to cast a wider search net [20]. Inclusion criteria have been adopted based on the Boolean strategy, which included "active ageing" /"active aging" in the title and in the abstracts with the following terms: "model," "definition," "theory," "structure," "dimension," and "attributes". Then, after collecting the fulltext studies, some terms were excluded to avoid overlapping, eg, aging, healthy aging, successful aging, and aging well. The key searched terms were classified into the following categories: (1) active aging (older people, elderly people); (2) built environment (built environment, housing, and building capacity); and (3) health outcomes (mental health, physical health, social health, wellness, well-being, disability, quality of life, comorbidity, functional limitations, disabled persons, and mentally disabled persons) (Fig. 2).

\section{Data extraction and quality assessment}

The results were recorded in a reference manager database and the titles and abstracts were screened by the main reviewer (AL). The team members verified the records with respect to their rigor and completion through secondary blind screening of $30 \%$ of the original 1500 records. Then, studies that met the inclusion and exclusion criteria (Table 1) were again checked and regular meetings were held to resolve the disagreement, if any, and discuss the review process.

\section{Data analysis}

Narrative synthesis, along with qualitative content analysis based on mixed inductive and deductive approaches, was used for data analysis through identifying the themes emerging from the evidence $[17,18]$. The steps of qualitative content analysis were organized according to Renz et al. (2018), which included "(a) preparing the data, (b) reading transcripts repeatedly to achieve immersion and obtain a sense of the whole, (c) making notes on the transcripts listing the different types of information found in the text, (d) defining the unit of analysis using themes as the unit of analysis versus linguistic units, (e) developing a coding scheme to organize data in a comprehensible way, (f) coding all the 


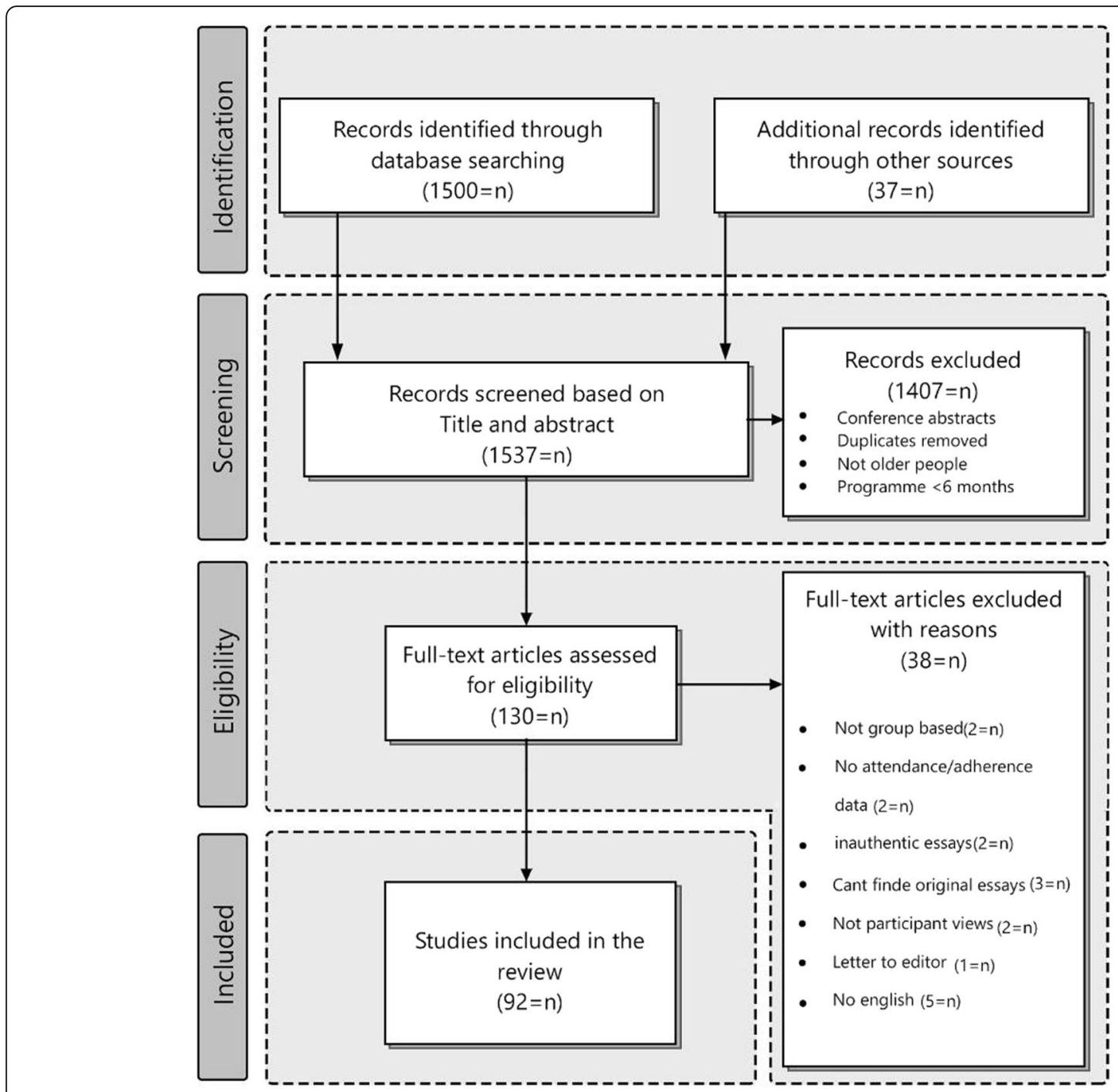

Fig. 2 Flow Chart of Study Selection

texts, (g) making conclusions from coded data, and (h) describing and interpreting the findings [26].

The aim of this study was to investigate the current body of research on ecological aspects of active aging. As defined by $\mathrm{WHO}$, active aging includes the following attributes ( [27], 1) autonomy: controlling, coping, and making personal decisions based on personal rules and preferences, (2) independence, the ability to perform functions related to daily living-that is the capacity of living independently in the community with no and/or little help from others; and (3) quality of life: an individual's perception of their position in life in the context of the culture and value system where they live and in relation to their goals, expectations, standards, and concerns. Active aging, as a broad-ranging concept, incorporates a person's physical health, psychological state, level of independence, social relationships, personal beliefs, and relationship to salient features in the environment [28].
As age increases, the quality of life the person becomes mainly dependent on their independence and autonomy and their healthy life expectancy. Positive subjective well-being, continued involvement in one's family, peer group, and community, good physical, social, and mental health, and good functional ability and fitness are among the components recognized to define active aging $[4,5]$.

The concept of active aging is the result of several components which help to identify the factors that act both as risks and supporting elements of active aging. The ecological approach is a general approach to geriatrics which focuses on multiple effective levels and helps to increase the level of physical activity in the total population, particularly the elderly as a separate group [29]. The proposed model provided the authors with an inclusive approach to understand the effective factors on physical activity based on which influential interventions could be offered for behavioral change [30]. 
Figure 2 shows the study selection process and exclusions. The search identified 1500 studies, of which 92 articles were eligible to be included in this review. Also, 48 articles included quantitative and mixed methods, while the remaining 45 studies applied qualitative methods and reviews. The 2 coauthors (AL and PR) independently performed data extraction, theme identification, and narrative summarization. Moreover, discussions with the other coauthor (HB) led to resolving discrepancies. Data synthesis began with an initial narrative evaluation of study characteristics and was completed with data reduction and comparison (Table 2).

\section{Identification of studies}

Qualitative and quantitative data were extracted from one of the articles with mixed method (Barnett et al. (2017. To use the iterative search approach, some other articles underwent screening for key authors searches, reference searches, and citation searches. Next, the full-text studies were analyzed based on the inclusion/exclusion criteria (Table 1). Then, the lead author (AL) organized the data extracted from each study into larger subthemes and themes and other members of the research team verified the process.

\section{Results}

A matrix was offered which included an outline containing the year, population, country, research method, and aspects of active aging concept (Appendix 1 and 2). The majority of the articles have been conducted during 2002 to 2018 and only a few have recently been published (eg, Ko \& Yeung (2018)). Also, most of the articles were conducted in the U.S., and most of the quantitative studies used either surveys or second data analysis and follow-up methods. However, most frequently, quantitative studies focused on social engagement, physical, and mental wellbeing and built environment, while qualitative papers emphasized life satisfaction. Figure 2 demonstrates the flow chart adapted from preferred reporting items [27, 118].

\section{Thematic analysis}

Different aspects of active aging based on qualitative content analysis were coded and categorized during the process of data analysis, the results of which are shown in Table 2 in the form of codes, subthemes, and themes. Different aspects have also been presented and summarized in a matrix, with 15 subthemes and 5 themes called 5P model: (1) person (personal status), (2) process, (3) place (built environment), (4) policymaking, (5) and prime (Fig. 3).

\section{Themes}

\section{Person}

One of the core themes is "person" that can be divided into 2 subthemes: personal characteristics and behavioral attitude. Most studies conducted on active aging provided an analysis of the effects of personal aspect, including health, age, shared genetic attributes, educational level, socioeconomic status, ethnicity, self-efficacy, and exercise history [23]. In addition, many studies included diet and lifestyle factors which are related to the person's behavior such as adoption of a balanced diet and food restrictions [38]. These restrictive diets and eating habits appear to be aimed for a balance between the imposition of the aging physique and the limitations due to disease and sickness. Therefore, to maintain active aging, a healthy diet should be considered as a major component for older people to provide them with strong levels of health and well-being, which in turn help them experience growth and maturity [38]. Another component associated with the behavior aspect that can maintain active aging is the attitude towards these behaviors, because it can be modified at any point leading to a considerable increase in active aging [38]. Therefore, several studies found that those elderly who have never smoked or drank enjoyed a considerably better active aging compared to those with such habits [38]. Evidence also suggests that physical activity is a significant factor in active aging $[23,38]$.

\section{Prime}

The ecological model described by Stocks in the context of healthy environments is a broad framework which takes into account the physical environment and the psychosocial environment [119]. The proposed ecological model demonstrates the functional relationships between the aging person and the micro, meso, and macro system levels of the environment, along with the unstable equilibrium between environment and individual competence in very old age [118].

In this narrative review, "prime" is a reflection of health and components within the concept of health; namely, physical, mental, and social health. According to WHO definition, health is a state of complete physical, mental, and social well-being and not merely the absence of disease or infirmity [120]. This shows that several factors should be considered to grasp the idea of health, including biological, social, and psychological aspects.

The environment includes the natural and the man-made components alongside each other, which significantly affects the health state of an older person. Strong evidence supports the fact that living in an environment of low quality results in decreased physical health, associated with high prevalence of degenerative disease, incidence of falls, cardiovascular mortality, and reductions in longevity and increased disability, poor quality of life, and poor self-reported health $[23,42$, $53,54,57,67,77,87,88]$. Several mental health issues were also examined in the literature, including depression, anxiety, anger, psychological well-being, and cognitive functioning (mental processing, speed, and working memory) [23, $53,57,65,79,87,88,93,115]$. Social health [98] and wellbeing literature, on the other hand, focuses on the quality of interpersonal relationships between the members of a 
Table 2 Themes of Active Aging Extracted From the Narrative Review

\begin{tabular}{|c|c|c|c|c|}
\hline Themes & Sub-Themes & Codes & Definition & References \\
\hline \multirow[t]{21}{*}{ Person } & \multirow{18}{*}{$\begin{array}{l}\text { Personal } \\
\text { characteristic/ } \\
\text { determinants }\end{array}$} & Age & & \multirow[t]{10}{*}[7,23,31-34]{} \\
\hline & & Gender & & \\
\hline & & Education level & & \\
\hline & & Ethnicity & & \\
\hline & & Residential tenure & & \\
\hline & & Marital status & & \\
\hline & & Home ownership & & \\
\hline & & Household size & & \\
\hline & & Current driving license & & \\
\hline & & Employment & & \\
\hline & & Eating and drinking habitat & & {$[23,35]$} \\
\hline & & Family support & & {$[23,36]$} \\
\hline & & SELF-CARE & & {$[23,37]$} \\
\hline & & SELF-PROMOTION & & {$[23,37]$} \\
\hline & & Mutual-help & & {$[23,37]$} \\
\hline & & Self-esteem & & {$[23,37]$} \\
\hline & & Life satisfaction & & {$[23,38]$} \\
\hline & & Travel behavior & & {$[23,39]$} \\
\hline & \multirow{3}{*}{$\begin{array}{l}\text { Behavioral } \\
\text { attitude/ } \\
\text { determinants }\end{array}$} & Cigarette smoking & & \multirow{3}{*}{$\begin{array}{l}{[38]} \\
{[23,40]}\end{array}$} \\
\hline & & Alcohol consumption & & \\
\hline & & $\begin{array}{l}\text { Practicing exercises/ kind/frequency/length of } \\
\text { activity }\end{array}$ & & \\
\hline \multirow[t]{9}{*}{ Place } & \multirow[t]{6}{*}{ Land- use } & Shopping and obtaining services & $\begin{array}{l}\text { The arrangement of activities and the the } \\
\text { impact between trip origin and destinations } \\
\text { Amount of activity in a given area } \\
\text { The proximity of different land uses }\end{array}$ & {$[23,33,41-43]$} \\
\hline & & Service proximity & & {$[23,44]$} \\
\hline & & Public facilities & & {$[23,33,45]$} \\
\hline & & Land use mix diversity / land-use composition & $\begin{array}{l}\text { Amenities and facilities, such as library, } \\
\text { community center, local } \\
\text { shops, traditional clinics, community } \\
\text { outreach projects }\end{array}$ & {$[33,41,43,46-49]$} \\
\hline & & Facilities management & & [50] \\
\hline & & Exercise, sports, and recreation facilities & & {$[51,52]$} \\
\hline & \multirow[t]{3}{*}{ Access } & Connectivity & $\begin{array}{l}\text { Connectivity and inter-linkages: Layering and } \\
\text { sequence from } \\
\text { private zone to community gathering zone } \\
\text { and neighborhood } \\
\text { Directness and availability of alternative } \\
\text { routes through a neighborhood } \\
\text { Directness and availability to different } \\
\text { areas in a region, composed of } \\
\text { street system, sidewalk network, } \\
\text { pedestrian volumes, and directness } \\
\text { of route }\end{array}$ & {$[43,53-55]$} \\
\hline & & Accessibility services & $\begin{array}{l}\text { The proximity of the home block and its } \\
\text { neighborhood amenities } \\
\text { Systems that provide connections between } \\
\text { activities }\end{array}$ & {$[7,23,33,48,54,56-63]$} \\
\hline & & Physical activity/ walkable environment/ & $\begin{array}{l}\text { Pavements and roads; safe pedestrian } \\
\text { crossings } \\
\text { Pedestrian infrastructure, good sidewalks, }\end{array}$ & $\begin{array}{l}{[31,33,41-43,48,49,} \\
51,53-56,58,59,63- \\
77]\end{array}$ \\
\hline
\end{tabular}


Table 2 Themes of Active Aging Extracted From the Narrative Review (Continued)

\begin{tabular}{|c|c|c|c|c|}
\hline Themes & Sub-Themes & Codes & Definition & References \\
\hline & \multirow{9}{*}{ Physical form } & & $\begin{array}{l}\text { surface area of open } \\
\text { space, }\end{array}$ & \\
\hline & & Mobility & $\begin{array}{l}\text { Exterior and interior accessibility } \\
\text { Ease of activities, convenience, } \\
\text { disabled facilities, comfortable } \\
\text { movement }\end{array}$ & $\begin{array}{l}{[39,52,53,55,58,65} \\
71,78-81]\end{array}$ \\
\hline & & Transportation (public) & $\begin{array}{l}\text { Adequate and affordable public } \\
\text { transport; bus stops }\end{array}$ & $\begin{array}{l}{[7,33,57,58,60,68,71,} \\
75,79,82]\end{array}$ \\
\hline & & Neighborhood characteristics & $\begin{array}{l}\text { The number of noticeable differences } \\
\text { in a street; also defines the level of } \\
\text { the complexity of an environment, and, } \\
\text { thus, the interest in the pedestrian }\end{array}$ & {$[43,62]$} \\
\hline & & Urban Block: density & Lack of nuisance, free from crowds & {$[43,83,84]$} \\
\hline & & Safety: Traffic/speed, volume & & $\begin{array}{l}{[7,31,33,41,48,63,68,} \\
75]\end{array}$ \\
\hline & & $\begin{array}{l}\text { Security: Crime/personal security/fall } \\
\text { prevention architectural elements }\end{array}$ & $\begin{array}{l}\text { Perceived safety, access to protection, } \\
\text { environmental support, } \\
\text { close environment satisfaction, care, and } \\
\text { support from family, } \\
\text { social support and Medicare }\end{array}$ & $\begin{array}{l}{[7,41,42,44,53,54,60,} \\
85,86]\end{array}$ \\
\hline & & Access to nature and green spaces & $\begin{array}{l}\text { Contact with nature, green spaces, parks, } \\
\text { gardens, micro-climate }\end{array}$ & {$[53-55,79,87]$} \\
\hline & & Topography / slope & & [23] \\
\hline & \multirow{4}{*}{$\begin{array}{l}\text { Cityscape/City } \\
\text { Image }\end{array}$} & Perceived distance & & \\
\hline & & Legibility/image & $\begin{array}{l}\text { Way finding, understanding, and legibility } \\
\text { of directions }\end{array}$ & [64] \\
\hline & & $\begin{array}{l}\text { Perceived aesthetic/environmental } \\
\text { attractiveness }\end{array}$ & Attractiveness and appeal of a place & $\begin{array}{l}{[31,33,43,46,48,55} \\
63,75,85]\end{array}$ \\
\hline & & Natural scenery & & {$[33,41]$} \\
\hline & \multirow{9}{*}{$\begin{array}{l}\text { Public open } \\
\text { spaces }\end{array}$} & Street lighting & Outdoor lighting & {$[33,53,57,88]$} \\
\hline & & Pedestrian safety & & [9] \\
\hline & & Area of green and open spaces & & {$[89]$} \\
\hline & & Recreation/ public open spaces & & {$[90]$} \\
\hline & & Cleanness/lack of littering/vandalism/decay & $\begin{array}{l}\text { Physical comfort: Cleanliness, visual } \\
\text { attractiveness, }\end{array}$ & {$[43,54,55,75,85]$} \\
\hline & & Sufficient maintenance and management & $\begin{array}{l}\text { Maintain structural and planting quality, } \\
\text { upkeep of scenic beauty }\end{array}$ & {$[54,64]$} \\
\hline & & Pollution (air, visual, noise, litter ...) & fresh air, free from noise and congestion & {$[56]$} \\
\hline & & Pleasant environment & & [54] \\
\hline & & Landscape & $\begin{array}{l}\text { Outdoor seating/urban furniture/ } \\
\text { spatial setting } \\
\text { Seating area for rest, communal spaces, } \\
\text { special seating, talking } \\
\text { Spaces/ }\end{array}$ & {$[43,53-55,57,64]$} \\
\hline & \multirow[t]{6}{*}{ Housing } & Universal design/ Housing quality variable & & {$[47,68,91,92]$} \\
\hline & & Neighborhood Safety & & [9] \\
\hline & & Residential density/density of housing & & {$[41,47-49,93]$} \\
\hline & & Older Residential Care Facility & & [70] \\
\hline & & Outdoor gardens & & {$[56,94]$} \\
\hline & & Type of housing & & {$[95-97]$} \\
\hline \multirow[t]{2}{*}{ Process } & \multirow{2}{*}{$\begin{array}{l}\text { Social } \\
\text { Environment }\end{array}$} & Life expectancy & & {$[44]$} \\
\hline & & Quality of life / wellbeing & & {$[1,35,52,58,70,72,93]$} \\
\hline
\end{tabular}


Table 2 Themes of Active Aging Extracted From the Narrative Review (Continued)

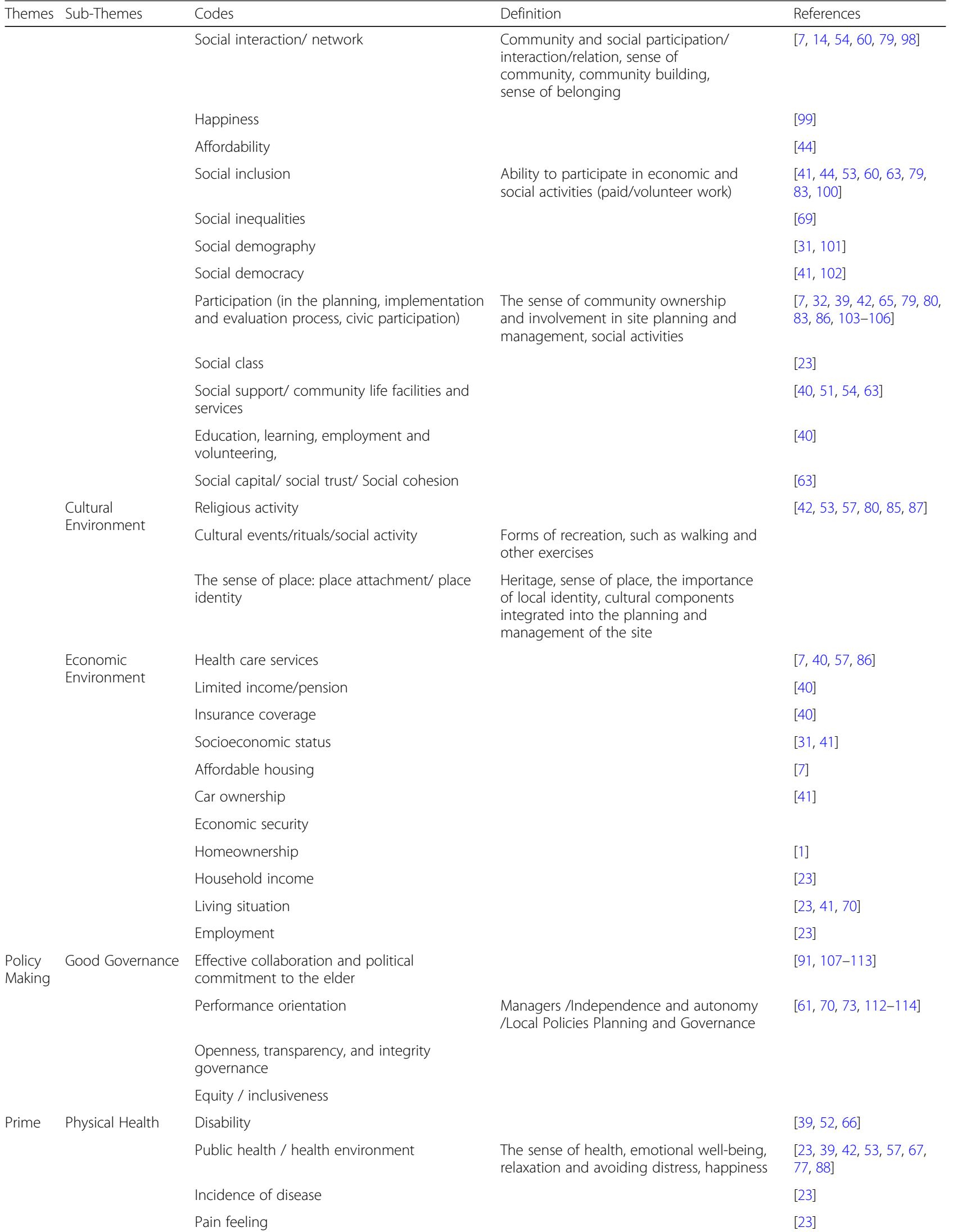


Table 2 Themes of Active Aging Extracted From the Narrative Review (Continued)

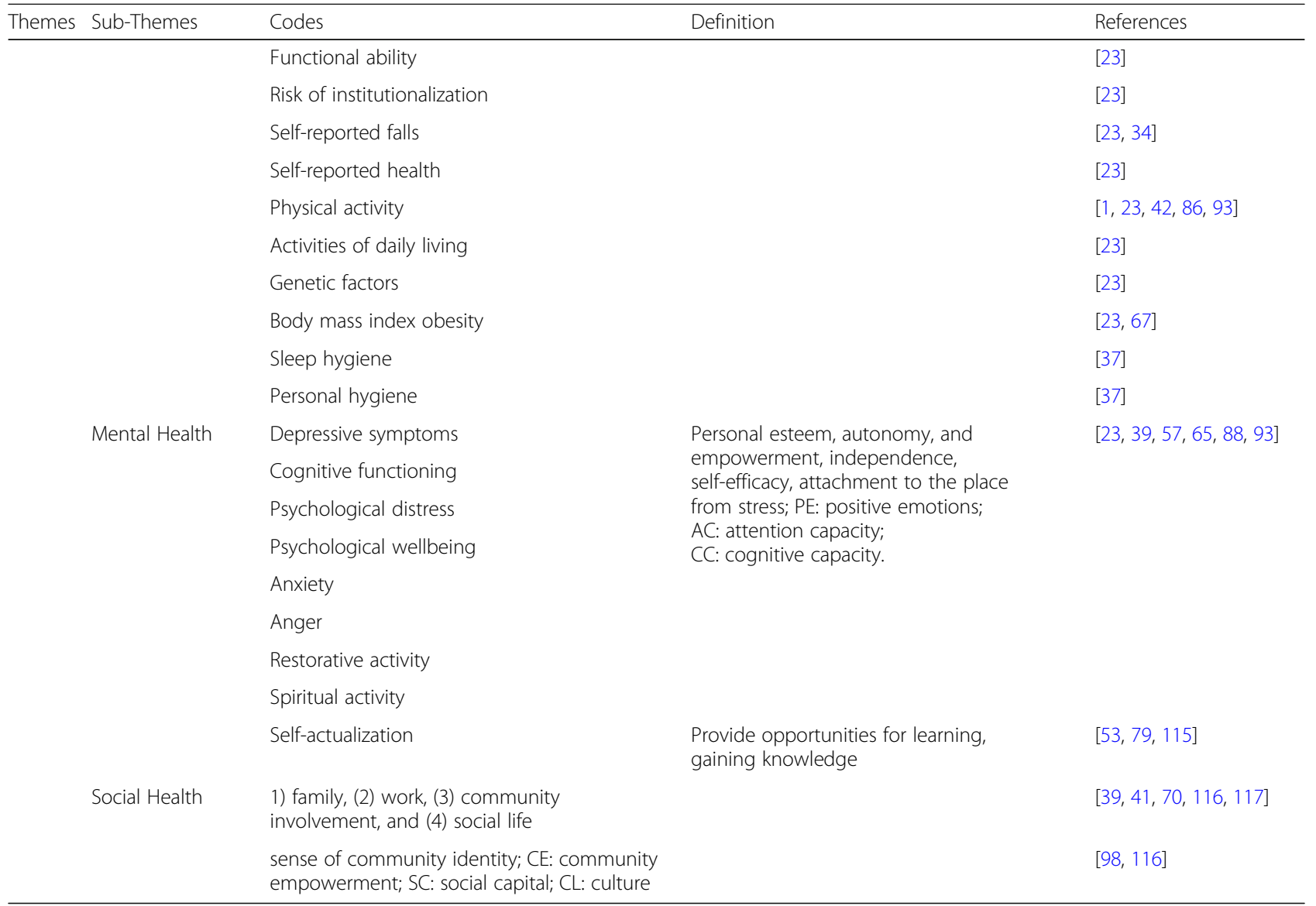

society and the amount of their involvement in their community. Several studies conducted on social well-being were assessed, and as a result of which it was found that to propose the level of social well-being for a group of people, their performance must be studied in the following areas: (1) family, (2) work, (3) community involvement, and (4) social life or sociability of individuals (eg, friendships) [117].

However, community health and psychological health are the results of the efforts contributed by epidemiologists and environmental psychologists, which include the sense of community identity, community empowerment, social capital, and culture [116].

\section{Process}

"Process" as the core ecological theme in active aging includes 3 subthemes: social, economic, and cultural environments, which are significantly important in the lives of an aging older person, as these can be barriers for life activities and may have health outcomes [23]. In this study, the literature search focused on those activities in the active aging policy framework by WHO that outlined key items as physical, social, cultural, civic, spiritual, and economic activities [2]. Many researchers have decided to study the role of social environement, which includes proximate social networks, social capital (norms of reciprocity and trust), and incidental social interactions [23]. Also, important components of social environement that affect an increased active aging include different social contacts, increased social involvement, wide social network, living children, ethnic homogenity, increased sense of neighborliness, increased literacy, increased social and economic status, increased workforce involvement, time spent with friends, and an age-specific community $[1,7,23$, $31,32,35,40-42,44,51-54,58,60,63,65,69,70,72,79,80$, $83,87,93,100-106,121]$.

There are some specific characteristics of the social environment that requires the elderly to meet specific demands leading to suboptimal active aging. These may include family's financial problems, a partner with health problems, unrealistic expectations of the person from their friends and families, and weak social and economic status of the area which is recognized as economic environment $[1,7,23,31$, $40,41,70,78,86]$. In addition, there is also the cultural environment which consists of religious activity, cultural events/ rituals/social activity, and sense of place [42, 53, 54, 57, 80, $85,87]$. In this study, based on strong evidence, it was found that a powerful and supportive social network enhances the well-being and longevity of the elderly in the society. However, the composition of this supportive network may differ 


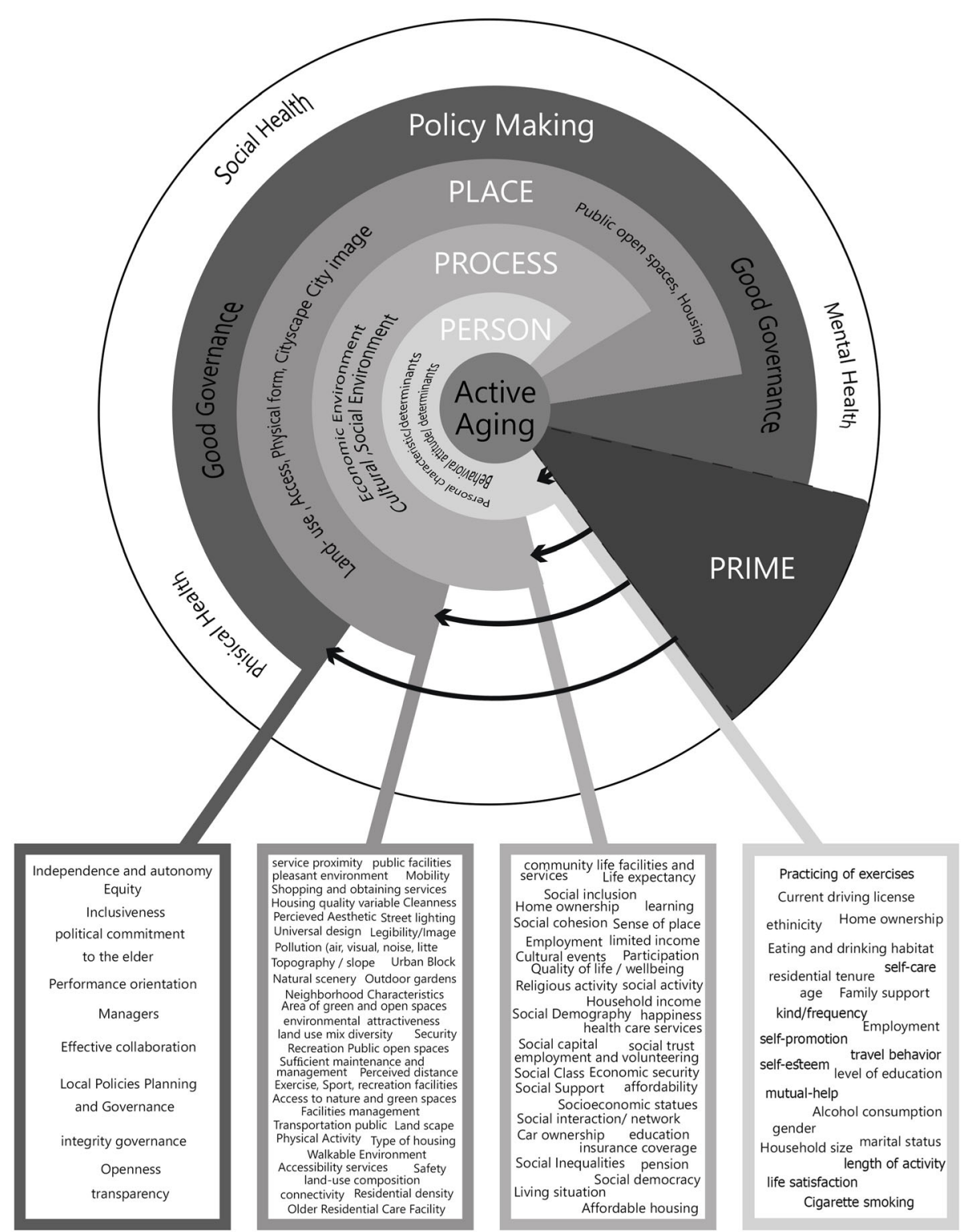

Fig. 3 5P Ecological Model of Active Aging

from one society/person to another [23]. The extent of poverty is also among the commonly mentioned factors that affects the activity involvement of the people. Yet, several studies maintained that lower social and economic status of an area is linked to the physical activity of individuals, which may be the case due to this group's need for work and transportation. In fact, active aging includes social, cultural, civic, spiritual, and economic elements, which potentially contribute to health and well-being in later life [2, 23].

\section{Place}

The theme of "place" consists of land use, physical form, housing themes, access, public space quality, and city image/ townscape. There are several reported environmental characteristics that enhance the elderly's well-being, including the proximity to and density of public open space and recreational facilities, high-quality facilities (social and leisure facilities, age-appropriate facilities), peacefulness, cleanliness, safety of public areas and street crossings, frequent rubbish collection, access to health services, transport availability, closeness to shops and places for walking, living in a retirement village, living in a hillside area, living in an area with high rainfall and living in a residential environment [23], and lack of littering/vandalism/decay [40].

Furthermore, those studies that have addressed the importance of place in the discussion of active aging were identified, which included the following factors: measures of land use characteristics (area deprivation or poverty, and 
neighborhood degradation) [23, 33, 41, 42, 44-51]; physical form (neighborhood degradation, accessibility to services and facilities, accessibility of public greenspace, walkability, or pedestrian friendliness) $[3,7,23,31,33,41,42,48,49,51-79$, 81, 82, 122]; physical form as security of perceived crime and antisocial behavior; safety of traffic conditions [7, 31, 33, 41, $42,44,48,53-55,60,62,63,68,75,79,83-87,123]$; quality of public space [23] as aesthetics and architecture, landscape (lighting and furniture) [33, 53-57, 64, 75, 85, 87-90], pedestrian-friendly features and availability of benches/sitting facilities [40]; trip hazards at home and neighborhood; home and environmental adaptations, climate and topography [23]; and favorable physical attributes such as trees and green areas which provide a sense of well-being and support resilience. Other positive factors were favorable street design, access to public transportation system, and several retail outlets which could be a motivating factor for more community involvement and physical activity $[10,33,53-55,57,64,75,85$, 87-90]. Identifying such diverse types of environments for careful analysis helps to assess homes or care centers and typology of land use, including rural and urban uses, categorization according to population density, defining areas based on time/distance, and defining a neighborhood by its members. Interestingly, in this review, it was found that most studies provided researcher-based definitions of a place as the built environment [23, 41, 47-49, 56, 68, 70, 77, 91-97].

\section{Policymaking}

Studying environments in the previous body of literature also included government-defined administrative areas as census tracts or postal codes [23], which focused on the key concepts of tolerance, fairness, social justice, and good governance (effective collaboration and political commitment to the elder performance orientation, openness, transparency, and integrity governance, and equity/inclusiveness) $[61,70,73,91,107-112,114,124,125]$ as necessary elements in sustainable development of urban planning. While physical and social environments are both important aspects to ensure the elderly's health state, favorable governance and planning of the environment are of significant importance in building an age-appropriate community. To this end, several models have been proposed to address this important issue. However, the results showed that consensus planning using meaningful community involvement is significantly needed for these complex areas. Moreover, collaborative governance efforts with different players and sectors through the stages of building a community are also of great importance, as the public was considered as a body to consult with rather than active members in developing knowledge, space, or governance centers [126].

\section{Study quality}

A considerable number of the included articles clearly provided objectives and methods compatible with the aims of their research. Comprehensive details of the studies' quality are provided in appendices 1 and 2 . In brief, since many of these articles applied a self-selected sampling, their results were enormously influenced by selection and information bias, which could affect their internal validity and, perhaps, the quality of quantitative studies, and to a lesser extent, qualitative studies. Furthermore, there were some observational studies which could not be considered as transferable and generalizable due to their small sample size and the methods used. This review was based on a qualitative process considering different aspects, which can provide different requirements for international scales, different types, etc. An iterative review, including all relevant literature to derive themes to accommodate smaller qualitative pieces of work that may have specific implications to international communities, small or large, with diverse societal, cultural, and religious belief systems, was conducted.

\section{Discussion}

This narrative review was systematically conducted with the aim of defining the concept of active aging based on the ecological model. According to the findings, a 5P model, with 5 themes, including person, prime (health), process, place, and policymaking and 15 subthemes, was developed as the main framework of the ecological model of active aging. This framework provides the notion of the concept of active aging as a multidimensionality, multilayered (environment), and contextual concept from an ecological standpoint. Several results were obtained, and the first of which included specifications of the aging sample of the previous research most of whom were 65 years. However, based on WHO (2002), the old age is defined as 60 years or older. In addition, the age of the participants in different studies varied considerably, which made data comparison impossible, and there was also a lack of a mutual base for a functional definition of this concept.

The multidimensional concept of active aging does not merely focus on the physical activity of the older person alone, but it also consists of individual, social, and physical components, policymaking process, and environments with regards to physical activity, health, and the context in which such activities occur. In fact, this is in line with the previous body of research considering active aging as a multidimensional concept $[23,42]$. According to the multilayered environmental nature of active aging, the findings of this study represent a notion that begins with an individual layer (person) and includes individual characteristics and behavioral attitudes, social or physical environment layer, and policymaking environment. However, these factors are closely linked together and all elements need to function harmoniously to achieve active aging in the context of societal, cultural, and religious belief systems. Indeed, this concept represents an ecological model $[45,127,128]$ which focuses on the relationships between the environmental 
levels of the aging person within the 5P model, taking into account the micro (person), meso (process), and macro systems (place and policymaking) based on health (prime) dimension, along with the unstable equilibrium between environmental and individual competence in old age [118].

Active aging with contextual nature as a cultural and social notion [129] has its roots in diverse environmental contexts to clarify the ways a person reacts to and interacts with the environment they live in $[128,130]$. According to Baltes' theory of lifespan development (1987), throughout life, development always consists of the joint occurrence of gain (growth) and loss (decline) [49]. Considering the findings of this narrative review, active aging is a fruit of both personal and sociocultural environments which are strongly linked to the themes of policymaking and place according to the definition of health (prime). Perhaps the most important fact to be considered is that the aging population should be equipped with the necessary support to maintain an equilibrium between their decreased physical ability and increased transcendence, which is significantly obtained through access to personal, environmental, and social resources. This equilibrium includes physical and mental health at the micro level (personal), social well-being, and spirituality/transcendence (process) at the meso level, while living in a favorable and appropriate environment. Figure 3 demonstrates the details on policymaking that can ensure effective active aging.

This review was the first interdisciplinary and multidisciplinary study to define active aging. As active aging is a vast concept, it is essential to provide a multidisciplinary approach which covers its different aspects. Also, focusing on the elderly's needs, including the need for active life with healthy behaviors results in their long-term positive outcomes which are of low cost and high value [131]. Moreover, to reach such a goal, the authors defined active aging as trying to maintain the components of health through participation in activities consistent with the individual's objectives, abilities, and opportunities using the ecological model, which include 4 pillars of active aging for the elderly: goals in life, abilities, opportunities, and activities. In this narrative review, it was found that although the concept of active aging enhances the health status of individuals [132], the concept is faced with a few methodological issues. This methodological issue included the heterogeneity of the final studies and mapping factors of active aging, while focusing on the built environment. However, this review aimed to explore the socioecological approach which is motivating enough to create lifestyle changes in the elderly. Also, there were several contradictions between the reviewed studies, which could be due to several factors, including the novelty of this area of research in environmental gerontology, limited survey tools, or the fact that there is no diversity of theories on the potential combination of effects influencing well-being and activity in aging years. Several personal factors that had an effect on the health and activity of the elderly were identified and led to the realization of a mixed model of effects, which could be an interesting topic for future research.

In this study, a large number of studies written in English language contributed to a broader understanding of the dimensions of active aging. Nevertheless, conducting an integrative review is not a guarantee for finding all relevant articles on the subject of the investigation, as there might have been papers published in other languages than English. A further limitation which restricted the generalizability of the findings was the dearth of any conceptual base in the majority of the studies. Only the study of WHO (2002) sought to conceptualize models for different aspects of active aging.

\section{Conclusion}

This narrative review described the aspects of active aging on a voluminous body of research conducted on the active aging concept using the ecological approach. The results of this study showed that personal characteristics, sociocultural and economic environments, place, and policymaking lead to more health and active life in the elderly (active aging). Also, most reviewed articles proposed that environmental conditions (built, natural, social, cultural, and economic statuses) are among the major factors affecting the elderly's active aging. However, a few studies claimed that there are no links between environment and active aging. Yet, these articles should pay attention to the effects of the environment in micro, meso, and macro levels, as described in the ecological model. This is while strength, direction, and experience of environmental elements may be different among individuals, communities, and health outcomes in aging years. Future research may focus on the broad topic of environmental gerontology to provide a piece of comprehensive knowledge of the links between environment, aging, health, and activity. Future studies should pay attention to the following factors: conducting qualitative or mixed methods to allow a more detailed exploration; higher levels of collaboration with elderly stakeholders through the research stages and policymaking environment; a more focused consideration of activity participation not only for physical aspects; creating new socioecological models and theories to explain the personal and environmental effects on health and activity; and paying more attention to active aging and relationships between the significant areas of activity participation.

We propose the following definition for the active aging process: "Active Aging is a process through which an individual tries to maintain the components of health by participating in activities consistent with their objectives, abilities, and opportunities in the community, which can be described as what they want to do and can do, and opportunities to do the activities they enjoy."

Also, this study proposes a 5P model, which provides a comprehensive knowledge of diverse aspects of active aging that could be used to benchmark successful active aging and also offers a framework for future research on this topic. 


\section{Appendix 1}

Table 3 Quantitative and mixed studies of active Aging

\begin{tabular}{|c|c|c|c|c|c|}
\hline NO & NAME & TYPE OF STUDY & POPULATION & COUNTRY & DIMENTION OF ACTIVE AGING \\
\hline 1. & [1] & $\begin{array}{l}\text { Integrative review (This } \\
\text { method includes both } \\
\text { qualitative and quantitative } \\
\text { studies) }\end{array}$ & $\begin{array}{l}\text { First, } 2543 \text { articles } \\
\text { Then } 76 \text { articles were eligible }\end{array}$ & Iran & $\begin{array}{l}\text { Social well-being, psychological } \\
\text { wellbeing, physical health, spirituality } \\
\text { and transcendence, and environment } \\
\text { and economic security. }\end{array}$ \\
\hline 2. & [9] & Survey study & $\begin{array}{l}\text { Shapefile sources include the } \\
\text { United States Census Bureau }\end{array}$ & USA & $\begin{array}{l}\text { Walkability, built environment, } \\
\text { physical activity, older adults, } \\
\text { objective measures, subjective } \\
\text { measures, active aging, GIS, } \\
\text { neighborhood, urban health }\end{array}$ \\
\hline 3. & [33] & $\begin{array}{l}\text { multi-method approach } \\
\text { (a systematic review and } \\
\text { meta-analysis) }\end{array}$ & $\begin{array}{l}100 \text { articles from peer-reviewed } \\
\text { and grey literature older adults } \\
\text { ( } \geq 65 \text { years old })\end{array}$ & Australia & $\begin{array}{l}\text { Walkability, residential density/ } \\
\text { urbanization, street connectivity, } \\
\text { access to/availability of destinations } \\
\text { and services, infrastructure and } \\
\text { streetscape, and safety }\end{array}$ \\
\hline 4. & [23] & $\begin{array}{l}\text { Cohort and Followed up } \\
\text { study }\end{array}$ & $\begin{array}{l}883 \text { participants aged } 55 \text { years } \\
\text { and older }\end{array}$ & USA & $\begin{array}{l}\text { Traffic, noise, crime, trash and } \\
\text { litter, lighting, and public } \\
\text { transportation }\end{array}$ \\
\hline 5. & [36] & prevalence-based method & $\begin{array}{l}17 \text { years of data at age } 65 \text { with } \\
\text { and without disabilities }\end{array}$ & Mexico & Disabilities \\
\hline 6. & {$[37]$} & Longitudinal study & 400 elderly At 60 years of age & Mexico & $\begin{array}{l}\text { High blood pressure, type2 } \\
\text { diabetes mellitus, cancer, } \\
\text { arthritis, osteoporosis, depression, } \\
\text { and dementia }\end{array}$ \\
\hline 7. & [38] & Quantitative approach & $\begin{array}{l}235 \text { elderly ranged between } 60 \\
\text { and } 94 \text { years old }\end{array}$ & Brazil & $\begin{array}{l}\text { Life satisfaction, leisure activities, } \\
\text { cigarette smoking, alcohol } \\
\text { consumption, practicing of } \\
\text { exercises, frequency, activity } \\
\text { length, about diet }\end{array}$ \\
\hline 8. & [39] & Quantitative approach & $\begin{array}{l}\text { totalsampleof48adults aged } 55 \\
\text { years and over, comprising } 4 \\
\text { subsamples of equal numbers } \\
(n=12)\end{array}$ & Australia & Self-ratings of being active \\
\hline 9. & [40] & Pre- and post-series survey & $\begin{array}{l}\text { older adults older than } 65 \text { years } \\
(n=23)\end{array}$ & USA & $\begin{array}{l}\text { Longevity, independence, fitness, } \\
\text { and engagement }\end{array}$ \\
\hline 10. & [41] & $\begin{array}{l}\text { Scoping study and macro- } \\
\text { level analyses }\end{array}$ & age 60 or 65 & Canada & $\begin{array}{l}\text { Participation, shopping and } \\
\text { obtaining services, active sports, } \\
\text { socializing and social participation, } \\
\text { car users and non-car-users }\end{array}$ \\
\hline 11. & [42] & Comparative study & $\begin{array}{l}799 \text { community-dwelling older } \\
\text { adults between } 65 \text { and } 74 \text { years } \\
\text { old }\end{array}$ & Canada & Health, participation, and security \\
\hline 12. & [43] & $\begin{array}{l}\text { Systematic review and } \\
\text { meta-analysis }\end{array}$ & aged $\geq 65$ years & - & $\begin{array}{l}\text { Older adults, Active travel, Cycling, } \\
\text { Walking, Neighbourhood, Built } \\
\text { environment }\end{array}$ \\
\hline 13. & [45] & Longitudinal Study & $\begin{array}{l}\text { aged } 50 \text { years and above } 307 \\
\text { communities }\end{array}$ & China & $\begin{array}{l}\text { Economic, institutional, and } \\
\text { sociodemographic environments } \\
\text { paid work, domestic care, } \\
\text { participation in community } \\
\text { and leisure activities }\end{array}$ \\
\hline 14. & [46] & $\begin{array}{l}\text { Structural Equation } \\
\text { Models (SEM) }\end{array}$ & $\begin{array}{l}402 \text { older persons ( } \geq 55 \text { years } \\
\text { of age) }\end{array}$ & Singapore & $\begin{array}{l}\text { high-density urban neighborhood, } \\
\text { well connected street, diversity of } \\
\text { land use mix, close proximity to } \\
\text { amenities and facilities, and } \\
\text { aesthetic environment }\end{array}$ \\
\hline 15. & {$[47]$} & Multiwave study & $\begin{array}{l}\text { Over } 10 \text { years. In-person } \\
\text { interviews were conducted with } \\
\text { a stratified random sample of } \\
4162 \text { community dwelling adults } \\
\text { aged } 65 \text { years and older residing }\end{array}$ & USA & $\begin{array}{l}\text { Intra-individual (e.g., psychosocial } \\
\text { attributes, coping styles, activity } \\
\text { accommodations) and extra-individual } \\
\text { (e.g., rehabilitation, external supports, } \\
\text { and the built, physical, and social }\end{array}$ \\
\hline
\end{tabular}


Table 3 Quantitative and mixed studies of active Aging (Continued)

\begin{tabular}{|c|c|c|c|c|c|}
\hline $\mathrm{NO}$ & NAME & TYPE OF STUDY & POPULATION & COUNTRY & DIMENTION OF ACTIVE AGING \\
\hline & & & in 5 contiguous counties & & environment) \\
\hline 16. & [48] & Cross-sectional studies & $\begin{array}{l}\text { Older women (mean age }=69.6 ; \\
n=136 \text { ) and women diagnosed } \\
\text { with MS (mean age }=46.1 ; \\
n=173 \text { ) }\end{array}$ & USA & $\begin{array}{l}\text { Self-efficacy, functional limitations } \\
\text { and street connectivity }\end{array}$ \\
\hline 17. & [49] & Followed up study & $\begin{array}{l}\text { age } 65-79 \text { years } \\
5218 \text { older }\end{array}$ & Western Australia & $\begin{array}{l}\text { Depression, depressive disorder, mood } \\
\text { disorder, mental health, risk factors social } \\
\text { context }\end{array}$ \\
\hline 18. & {$[52]$} & Cohort study & $\begin{array}{l}1000 \text { participants aged } 75, \\
80 \text { or } 85 \text { years }\end{array}$ & Finland & $\begin{array}{l}\text { Wellbeing, disability, environmental and } \\
\text { social support, mobility, health behavior } \\
\text { and health literacy }\end{array}$ \\
\hline 19. & [61] & Survey & $\begin{array}{l}\text { ages } 65-95 \text { ( } 45 \text { female } \\
\text { and } 55 \text { male) }\end{array}$ & Turkey & $\begin{array}{l}\text { Liveable urban environments, Accessible } \\
\text { urban environments, social benefits and } \\
\text { opportunities, such as health, social life, } \\
\text { environment, well-designed, easy } \\
\text { recognizable }\end{array}$ \\
\hline 20. & {$[62]$} & $\begin{array}{l}\text { Quantitative approach } \\
\text { questionnaire survey }\end{array}$ & 385 older adults aged 60 to 75 & Malaysia & $\begin{array}{l}\text { Permeability, accessibility, and facilitators } \\
\text { to walking }\end{array}$ \\
\hline 21. & [63] & $\begin{array}{l}\text { Cross-sectional interview } \\
\text { survey data }\end{array}$ & 4183 older adults ( $\geq 60$ years) & Thailand & $\begin{array}{l}\text { Walkable neighborhood, neighborhood } \\
\text { aesthetics, neighborhood service } \\
\text { accessibility, neighborhood criminal } \\
\text { safety, neighborhood social trust, } \\
\text { neighborhood social support, and } \\
\text { neighborhood social cohesion. The } \\
\text { present study confirms the important } \\
\text { role of age-friendly neighborhoods in } \\
\text { terms of physical and social } \\
\text { environments }\end{array}$ \\
\hline 22. & [58] & Mixed method approach & 117 participants aged $55+$ years & China & $\begin{array}{l}\text { urban spaces and infrastructure } \\
\text { on mobility and well-being }\end{array}$ \\
\hline 23. & [64] & $\begin{array}{l}\text { Mixed-use(research method } \\
\text { consists of four phases called } \\
\text { as conceptual analysis, data } \\
\text { collection about the research } \\
\text { area and topic, evaluation of } \\
\text { results and discussion) }\end{array}$ & 68 users over 65 years & Turkey & $\begin{array}{l}\text { Roads, pollution, safety,insufficiency } \\
\text { of maintenance and management, } \\
\text { traffic and sociocultural problems }\end{array}$ \\
\hline 24. & [71] & Cohort study & $\begin{array}{l}435 \text { participants aged } 65+ \\
\text { years old }\end{array}$ & USA & $\begin{array}{l}\text { High mobility barriers and low } \\
\text { transportation facilitators }\end{array}$ \\
\hline 25. & [74] & Cross-sectional & $\begin{array}{l}356 \text { participants } 6 \text { to } 89 \\
\text { years old }\end{array}$ & Germany & $\begin{array}{l}\text { Intellectual Abilities, Processing } \\
\text { Speed, and Processing } \\
\text { Robustness }\end{array}$ \\
\hline 26. & [75] & Population based study & $(N=60)$ aged 55 and over & USA & $\begin{array}{l}\text { land use planning and } \\
\text { transportation }\end{array}$ \\
\hline 27. & [76] & Evidence- based & - & Australia & Urban form, parks, walking \\
\hline 28. & {$[77]$} & Multilevel regression & $\begin{array}{l}546 \text { community-dwelling } \\
\text { older adults }\end{array}$ & USA & $\begin{array}{l}\text { Education, Annual household } \\
\text { income, Gender, Walking } \\
\text { self-efficacy }\end{array}$ \\
\hline 29. & {$[80]$} & Mixed study & 97 neighborhood & USA & $\begin{array}{l}\text { Quality of life Aging population } \\
\text { Spatial demography Heritage } \\
\text { city space perception } \\
\text { Neighborhood Social networks }\end{array}$ \\
\hline 30. & {$[81]$} & Statistical methodology & 1188 older adults & USA & $\begin{array}{l}\text { Accessible features (e.g., } \\
\text { continuous barrier-free } \\
\text { sidewalks and proximity } \\
\text { of public transportation) }\end{array}$ \\
\hline 31. & [78] & $\begin{array}{l}\text { multilevel logistic growth } \\
\text { curve models }\end{array}$ & older adults (age $75+$ ) & USA & Mobility Disability \\
\hline 32. & [82] & $\begin{array}{l}\text { Multilevel linear regression } \\
\text { analyses }\end{array}$ & $\begin{array}{l}20 \text { selected neighborhoods } \\
\text { age ( } 65-74 \text { vs. Z75 years) }\end{array}$ & Belgium & $\begin{array}{l}\text { Walkability and health } \\
\text { outcomes }\end{array}$ \\
\hline
\end{tabular}


Table 3 Quantitative and mixed studies of active Aging (Continued)

\begin{tabular}{|c|c|c|c|c|c|}
\hline NO & NAME & TYPE OF STUDY & POPULATION & COUNTRY & DIMENTION OF ACTIVE AGING \\
\hline & & & participants (1750 in total) & & \\
\hline 33. & [83] & Survey study & $\begin{array}{l}65 \text { years and older } 27 \text { Swedish } \\
\text { informants interviewed }\end{array}$ & Sweden & $\begin{array}{l}\text { Architecture, Place making, } \\
\text { Residential homes }\end{array}$ \\
\hline 34. & [85] & Data analysis & 364 Independently (55-80 years) & Netherland & $\begin{array}{l}\text { Walking, Physical environment, } \\
\text { Pedestrians, Active transport }\end{array}$ \\
\hline 35. & [88] & Statistical Analysis & $\begin{array}{l}4000 \text { people aged } 65 \text { years } \\
\text { and over }\end{array}$ & Hong Kong & $\begin{array}{l}\text { Physical and mental components } \\
\text { of health, frailty, and mortality. } \\
\text { Socioeconomic position, lifestyle } \\
\text { factors }\end{array}$ \\
\hline 36. & [89] & $\begin{array}{l}\text { Cross sectional, } \\
\text { multilevel design }\end{array}$ & $\begin{array}{l}577 \text { residents (mean age }=74 \\
\text { years) } 56 \text { city }\end{array}$ & USA & $\begin{array}{l}\text { Density of places of employment, } \\
\text { household density, green and } \\
\text { open spaces for recreation, } \\
\text { number of street intersections }\end{array}$ \\
\hline 37. & [90] & $\begin{array}{l}\text { Choice-based conjoint } \\
\text { analysis }\end{array}$ & Participants $(n=1197)$ & Belgium & $\begin{array}{l}\text { Recreation Public open spaces } \\
\text { Park design naturalness, upkeep, } \\
\text { walking paths, outdoor fitness } \\
\text { equipment/playground, sport field, } \\
\text { benches, drinking fountain, peers, } \\
\text { mother with children and homeless } \\
\text { person }\end{array}$ \\
\hline 38. & [92] & Survey (questionnaire) & $\begin{array}{l}103 \text { participants, ranging in } \\
\text { age from } 72 \text { to } 86 \text { years old }\end{array}$ & France & Neighborhood satisfaction Well-being \\
\hline 39. & [94] & Cohort study & $\begin{array}{l}3144 \text { people born in } 1903, \\
1908,1913 \text {, or } 1918\end{array}$ & Japan & $\begin{array}{l}\text { Age, sex, marital status, baseline } \\
\text { functional status, and socioeconomic } \\
\text { status, Greenery filled public areas }\end{array}$ \\
\hline 40. & [95] & A Population-Based Survey & $\begin{array}{l}2619 \text { interviews } 65 \text { years } \\
\text { and over }\end{array}$ & South Australia & $\begin{array}{l}\text { Falls (including slips, trips and falls } \\
\text { to the ground) }\end{array}$ \\
\hline 41. & [96] & $\begin{array}{l}\text { Survey (multivariable } \\
\text { logistic regression) }\end{array}$ & $\begin{array}{l}4494 \text { elderly Singaporeans } \\
\text { (X60 years) }\end{array}$ & Singapore & $\begin{array}{l}\text { Age, gender, ethnicity, education, } \\
\text { housing type, living arrangement } \\
\text { and social participation) and health } \\
\text { (body mass, diabetes and cognitive } \\
\text { status) }\end{array}$ \\
\hline 42. & [97] & Quantitative approach & $\begin{array}{l}38,595 \text { elderly persons } \\
\text { ( } \geq 60 \text { years old) }\end{array}$ & India & $\begin{array}{l}\text { Age, tobacco smoking, education, } \\
\text { living standard, and other such } \\
\text { factors }\end{array}$ \\
\hline 43. & [99] & Quantitative approach & 400 participants Years old +60 & Iran & $\begin{array}{l}\text { Happiness, age, sex, satisfaction, } \\
\text { peace, level of activity, self-respect }\end{array}$ \\
\hline 44. & [98] & quasi-experimental study & $\begin{array}{l}\text { Seventy-six older adults aged } \\
60 \text { years and over part }\end{array}$ & Mexico & $\begin{array}{l}\text { Vital Aging, active aging, intervention } \\
\text { program, successful aging }\end{array}$ \\
\hline 45. & {$[100]$} & Quantitative approach & - & European countries & labor-market, suicide mortality \\
\hline 46. & [110] & $\begin{array}{l}\text { Multivariate logistic } \\
\text { regression }\end{array}$ & 1485 participants +90 years & USA & $\begin{array}{l}\text { Dementia, chronic diseases or } \\
\text { hospitalizations }\end{array}$ \\
\hline 47. & [112] & Descriptive-analytic study & $\begin{array}{l}379 \text { older adults and } 57 \\
\text { managers minimum } 60 \text { and } \\
\text { maximum } 89 \text { years }\end{array}$ & Iran & $\begin{array}{l}\text { Participation and Collaboration } \\
\text { of organizations }\end{array}$ \\
\hline 48. & [113] & $\begin{array}{l}\text { A mixed-method sequential } \\
\text { explanatory design }\end{array}$ & $\begin{array}{l}\text { all Canadian communities, } \\
\text { defined by the municipalities } \\
(N=3555)\end{array}$ & Canada & $\begin{array}{l}\text { 1) Describe and compare age-friendly } \\
\text { key components of communities across } \\
\text { Canada 2) Identify key components best } \\
\text { associated with positive health, } \\
\text { social participation and health equity } \\
\text { of aging adults } 3 \text { ) Explore how these } \\
\text { key components foster positive health, } \\
\text { social participation and health equity }\end{array}$ \\
\hline
\end{tabular}




\section{Appendix 2}

Table 4 Qualitative and review studies of active Aging

\begin{tabular}{lll}
\hline NO & NAME & TYPE OF STUDY \\
\hline 1. & {$[7]$} & Delphi study \\
2. & {$[14]$} & $\begin{array}{l}\text { Realist synthesis (is a method } \\
\text { of summarizing evidence for } \\
\text { public policy) }\end{array}$
\end{tabular}

3. [23] Systematic review

83 quantitative and qualitative studies

COUNTRY

over age 65

36peer-reviewed qualitative studies

A Systematized Review
Qualitative Evidence

5. [32] Synthesizing literature

6. [34] Systematic literature review

7. [35] Grounded theory

8. [44] Content-analyzed

9. [50] Qualitative approach

10. [51] Systematic review using a meta-ethnographic approach

11. [53] Design

12. [54] Literature review

13. [55] Content-analyzed
65 years of age or older aged 80 and over

$-$

In 33 cities, partners conducted 158 focus groups with persons aged 60 years and older
USA

$-$

USA

Global Age-Friendly Cities

Netherland

Hong Kong

60 years old or above

$-$

57 countries
DIMENTION OF ACTIVE AGING

Accessible and affordable transportation, housing, healthcare, safety, and community involvement opportunities

healthy Aging; mobility; neighborhood; public policy

Ethnicity and cultural norms, energy and motivation, sex, age, education, genetic heritage, self-efficacy, and personal financial circumstances, climate, level of pollution, street lighting, traffic conditions, accessibility and appropriateness of services and facilities, socio-economic conditions, aesthetics, pedestrian infrastructure, community life, exposure to antisocial behavior, social network participation, environmental degradation, level of urbanism, exposure to natural settings, familiarity with local environment and others. Recommendations for future research include the need for innovative research methods; involvement of older adults as research collaborators; investigation of wider aspects of the active Aging concept; in-depth assessment of the environmental characteristics of areas; investigation of the pathways leading from environment to health and activity participation.

Functional, aesthetic, destination, and safety built characteristics influence physical activity decision-making. Socio demographic characteristics (age, sex, ethnicity, and socioeconomic status) also impacted the BE's influence on physical activity

Bonding, bridging and linking capital (Social inclusion)

Quality of life, subjective well-being, aged, exercise, physical activity

Body, person and societal level, the person-environment contextual factors

Outdoor spaces and buildings; transportation; housing; social participation; respect and social inclusion; civic participation and employment; communication and information; and community support and health services

Sensory, physical, neural and cognitive functions, housing, safe environment

Social, behavioral, biological and psychological factors

Physical, mental and social wellbeing, health, mobility/ability, material circumstances, activities, happiness, youthfulness and living environment

Hong Kong Open spaces, social needs

Public health security 
Table 4 Qualitative and review studies of active Aging (Continued)

\begin{tabular}{|c|c|c|c|c|}
\hline $\mathrm{NO}$ & NAME & TYPE OF STUDY & POPULATION & COUNTRY \\
\hline 14. & {$[56]$} & $\begin{array}{l}\text { Experience design } \\
\text { approach }\end{array}$ & 65 years and over & Australia \\
\hline 15. & {$[57]$} & Critical review & - & USA \\
\hline 16. & {$[59]$} & Literature review & 75 article & USA \\
\hline 17. & {$[60]$} & Literature review & - & Czech Republic \\
\hline 18. & {$[65]$} & Qualitative approach & - & USA \\
\hline 19. & {$[66]$} & Systematic review & 2039 article & USA \\
\hline 20. & [67] & Concept study & - & Australia \\
\hline
\end{tabular}

DIMENTION OF ACTIVE AGING

Architectural design thinking; user-

centric building design; environmental experience design; residential aged care facilities

Health, functioning, and social participation, wellbeing

Safety, microscale urban design elements, aesthetics, and convenience of facilities

Satisfaction, landscape, function

Social, economic, demographic, and physical characteristics

Disability Built environment Physical activity

Biological, psychological, behavioral, and social factors include development intensity, land use mix, fine grain economy, adaptability, permeability, streets, contact, visibility and horizontal grain, public realm, movement, green space and water space, landmarks, legibility, comfort, diversity, richness, continuity, contrast, intelligibility, interest, intimacy, openness, rhythm, texture, and human scale.

21. [68] Qualitative approach

USA

Neighborhood design and safety, housing, transportation, and mobility. Strategies to build capacity for policy change

$\begin{array}{lll}\text { 22. [69] } & \text { Systematic review } \\ \text { 23. [70] } & \text { Review Article } \\ \text { 24. [72] } & \text { Summative Review } \\ \text { 25. [73] } & \text { Qualitative approach }\end{array}$

aged 50 years and over

Bremen, Germany

Physical activity, Social inequalities

172 review articles aged 65 or older

over 65 years old

$-$

Australia

Active and healthy living; features medical research

Physical activity

Portugal

Irradiation, Connectivity, Conspicuous, Suitability/Convenience, Readability, Comfort

26. [79] Concept study

over 65 years

Poland

USA

China

Herston, Australia

Pensions and income. Economy and employment. Health care and other services. Rights of individuals. Housing and communities.

Built environment, walking, and health

Civic participation

$-$

$-$

29. [87] Concept study

30. [91] Structured review

1464 articles

UK

gerontology, public health, environmental psychology, landscape architecture, and urban design personally meaningful outdoor activities, environmental attributes

Health and social services, behavioral determinants, personal determinants, physical environment, social determinants and economic determinants income, health, housing, transport, living in the community, MAori cultural identity, access to facilities and services, attitudes, employment, and opportunities

Poor street condition, Heavy traffic, Public transit line nearby, Housing 
Table 4 Qualitative and review studies of active Aging (Continued)

\begin{tabular}{|c|c|c|c|c|c|}
\hline $\mathrm{NO}$ & NAME & TYPE OF STUDY & POPULATION & COUNTRY & DIMENTION OF ACTIVE AGING \\
\hline & & & & & $\begin{array}{l}\text { variable, Environmental barriers, } \\
\text { Magnitude of accessibility problems, } \\
\text { Housing satisfaction, Usability (Physical } \\
\text { environmental aspects), Housing } \\
\text { amenities,Satisfaction with home } \\
\text { environment, Satisfaction with outdoor } \\
\text { environment,Place attachment, Housing } \\
\text { accessibility,Housing comfort, } \\
\text { Neighborhood quality, Outdoor place, } \\
\text { Life Satisfaction, Interior environment, } \\
\text { Exterior environment, Residential } \\
\text { satisfaction,Psychological wellbeing, } \\
\text { Street noise, Safety from traffic, Park } \\
\text { density, Train stations, ... }\end{array}$ \\
\hline 32. & [101] & Concept study & - & & $\begin{array}{l}\text { Social, demographic, financial and } \\
\text { political }\end{array}$ \\
\hline 33. & {$[102]$} & Concept study & - & - & Economic justice, satisfying, publicity, \\
\hline 34. & {$[106]$} & Concept study & - & & $\begin{array}{l}\text { Health, participation, Aging, and } \\
\text { independence }\end{array}$ \\
\hline 35. & [103] & $\begin{array}{l}\text { Technology-based information, } \\
\text { generic ACTION participatory design } \\
\text { model }\end{array}$ & - & West Sweden & $\begin{array}{l}\text { Dementia; information and } \\
\text { communication technology; } \\
\text { participatory design; partnership } \\
\text { working; user involvement }\end{array}$ \\
\hline 36. & [104] & Qualitative approach & - & UK & $\begin{array}{l}\text { Inequalities; urban health; older } \\
\text { people's quality of life }\end{array}$ \\
\hline 37. & {$[105]$} & $\begin{array}{l}\text { Qualitative research design } \\
\text { (Data derived from GPS } \\
\text { tracking, travel diaries, brief } \\
\text { questionnaires, and semi } \\
\text { structured interviews were } \\
\text { gathered) }\end{array}$ & $\begin{array}{l}13 \text { people aged from } 56 \\
\text { to } 87 \text { years }\end{array}$ & Australia & $\begin{array}{l}\text { Choice of transportation and its } \\
\text { relation to participation }\end{array}$ \\
\hline 38. & [107] & Concept study & - & & Population health \\
\hline 39. & [108] & $\begin{array}{l}\text { Qualitative analysis } \\
\text { Focus groups }\end{array}$ & $\begin{array}{l}\text { questionnaire had } 57 \text { questions } \\
\text { Participants included } 18 \text { elderly } \\
\text { (aged over } 60 \text { ), five family careers } \\
\text { and five professionals }\end{array}$ & Netherland & $\begin{array}{l}\text { Participatory design, patient } \\
\text { empowerment and cognitive usability }\end{array}$ \\
\hline 40. & [109] & Qualitative approach & - & USA & $\begin{array}{l}\text { Social, physical, and political residential } \\
\text { and business zoning, parks and } \\
\text { recreation, transportation, public health, } \\
\text { public safety, health services facilities, } \\
\text { private sector investment, employment, } \\
\text { and taxation }\end{array}$ \\
\hline 41. & [111] & Qualitative approach & - & Hong Kong & $\begin{array}{l}\text { Perspectives of stakeholders_-including } \\
\text { policy makers, service providers, and } \\
\text { elderly learner, quality of life and } \\
\text { well-being, }\end{array}$ \\
\hline 42. & [114] & Literature review & 32articles & Australia & $\begin{array}{l}\text { 'Age-friendly', 'elderly friendly', 'livable } \\
\text { community', 'lifetime neighborhood' and } \\
\text { 'community for all ages'. }\end{array}$ \\
\hline 43. & {$[116]$} & literature review & - & & $\begin{array}{l}\text { Public health, human well-being, green } \\
\text { infrastructure, urban ecosystem, ecosys } \\
\text { tem health }\end{array}$ \\
\hline 44. & [117] & literature review & $\begin{array}{l}19 \text { elderly residents } \\
\text { (aged } 65 \text { years and over) }\end{array}$ & Australia & Social health; social life \\
\hline 45. & [133] & Qualitative approach & Adults (66-97 years) & Washington & $\begin{array}{l}\text { Policy, exercise, obesity, built } \\
\text { environment, finite mixture modeling }\end{array}$ \\
\hline
\end{tabular}




\section{Abbreviations}

Al: The Author; HB: The Author; PR: The Author; UN: United Nation; WHO: World Health Organization

\section{Acknowledgements}

Not applicable.

\section{Authors' contributions}

PKM and HRB designed the scoping review and conducted the searches. AL and PR made substantial contributions to the conception of the review to extract the themes and subthemes by reviewing all materials in the analysis phase. AL drafted the manuscript with editorial and content input from all other authors. All authors have read and approved the final version of the manuscript.

\section{Funding}

The authors received no financial support for this research study.

\section{Availability of data and materials}

Not applicable.

\section{Ethics approval and consent to participate}

Not applicable.

\section{Consent for publication}

Not applicable.

\section{Competing interests}

The authors declare that they have no competing interests.

\section{Author details}

'Faculty of Architecture and Urban Planning, Shahid Beheshti University, Tehran 1983963113, Iran. ${ }^{2}$ Ageing Clinical \& Experimental Research Team, Institute of Applied Health Sciences, University of Aberdeen, Aberdeen, UK. ${ }^{3}$ Ageing Clinical \& Experimental Research Team, Institute of Applied Health Sciences, University of Aberdeen, Aberdeen, UK. ${ }^{4}$ Department of Epidemiology, School of Public Health, Iran University of Medical Sciences, Tehran, Iran.

\section{Received: 9 August 2019 Accepted: 30 December 2019}

Published online: 09 January 2020

\section{References}

1. Zanjari N, Sani MS, Chavoshi MH, Rafiey H, Shahboulaghi FM. Successful aging as a multidimensional concept: an integrative review. Med J Islam Repub Iran. 2017. https://doi.org/10.14196/MJIRI.31.100.

2. WHO. (2002). Active ageing: A policy framework.

3. Rodriguez-Rodriguez V, Rojo-Perez F, Fernandez-Mayoralas G, Morillo-Tomas R, Forjaz J, Prieto-Flores M-E. Active ageing index: application to Spanish regions. J Popul Ageing. 2017;10(1):25-40. https://doi.org/10.1007/s12062016-9171-1.

4. Fernández-Ballesteros R, Robine JM, Walker A, Kalache A. Active aging: A global goal. Curr Gerontol Geriatr Res. 2013;2013. https://doi.org/10.1155/ 2013/298012

5. Rantanen T, Portegijs E, Kokko K, Rantakokko M, Törmäkangas T, Saajanaho M. Developing an assessment method of active aging: University of Jyvaskyla Active Aging Scale. J Aging Health. 2019;31(6):1002-24. https://doi. org/10.1177/0898264317750449.

6. Lawton M, Nahemow L. Ecology and the aging process; 1973.

7. Alley D, Liebig P, Pynoos J, Banerjee T, Choi IH. Creating elder-friendly communities. J Gerontol Soc Work. 2007;49(1-2):1-18. https://doi.org/10 1300/J083v49n01_01.

8. Keller IM, Kalache A. Promoting healthy aging in cities: the healthy cities project in Europe. J Cross Cult Gerontol. 1997;12(4):287-98. https://doi.org/ 10.1023/A:1006539003961.

9. Weiss RL, Maantay JA, Fahs M. Promoting active urban aging: A measurement approach to neighborhood walkability for older adults. Cities Environ. 2010:3(1):1-17. https://doi.org/10.15365/cate.31122010.

10. Beard JR, Petitot C. Ageing and urbanization: can cities be designed to Foster active ageing? Public Health Rev. 2010;32(2):427-50. https://doi.org/ 10.1007/BF03391610
11. Brownson RC, Hoehner CM, Day K, Forsyth A, Sallis JF. Measuring the built environment for physical activity. Am J Prev Med. 2009;36(4):S99-S123.e12. https://doi.org/10.1016/j.amepre.2009.01.005.

12. Carr K, Weir PL, Azar D, Azar NR. Universal design: A step toward successful aging. J Aging Res. 2013;2013:1-8. https://doi.org/10.1155/2013/324624.

13. Haselwandter EM, Corcoran MP, Folta SC, Hyatt R, Fenton M, Nelson ME. The built environment, physical activity, and aging in the United States: A state of the science review. J Aging Phys Act. 2015;23(2):323-9. https://doi. org/10.1123/japa.2013-0151.

14. Yen $\mathrm{H}$, Anderson LA. Built environment and mobility of older adults: important policy and practice efforts. J Am Geriatr Soc. 2012;60(5):951-6. https://doi.org/10.1111/j.1532-5415.2012.03949.x.

15. Khan K, Ter Riet G, Glanville J, Sowden A, Kleijnen J. Undertaking systematic reviews of research on effectiveness: CRD's guidance for carrying out or commissioning reviews; 2001.

16. Oliver S, Harden A, Rees R, Shepherd J, Brunton G, Garcia J, Oakley A. An emerging framework for including different types of evidence in systematic reviews for public policy. Evaluation. 2005;11(4):428-46. https://doi.org/10. 1177/1356389005059383.

17. Dixon-Woods M, Agarwal S, Jones D, Young B, Sutton A. Synthesising qualitative and quantitative evidence: A review of possible methods. J Health Serv Res Policy. 2005;10(1):45-53. https://doi.org/10.1177/ 135581960501000110

18. Mays N, Pope C, Popay J. Systematically reviewing qualitative and quantitative evidence to inform management and policy-making in the health field. J Health Serv Res Policy. 2005;10(1_suppl):6-20. https://doi.org/ 10.1258/1355819054308576.

19. Barnett-Page $E$, Thomas J. Methods for the synthesis of qualitative research: a critical review. BMC Med Res Methodol. 2009;9(1):59. https://doi.org/10. 1186/1471-2288-9-59.

20. Booth A. Unpacking your literature search toolbox: on search styles and tactics. Health Info Libr J. 2008;25(4):313-7. https://doi.org/10.1111/j.14711842.2008.00825.x

21. Green $B N$, Johnson CD, Adams A. Writing narrative literature reviews for peer-reviewed journals: secrets of the trade. J Chiropr Med. 2006;5:101-17. https://doi.org/10.1016/S0899-3467(07)60142-6.

22. Gough D, Thomas J, Oliver S. Clarifying differences between review designs and methods. Syst Rev. 2012;1(1):28. https://doi.org/10.1186/2046-4053-1-28.

23. Annear M, Keeling S, Wilkinson T, Cushman G, Gidlow B, Hopkins H. Environmental influences on healthy and active ageing: A systematic review. Ageing Soc. 2014;34(4):590-622. https://doi.org/10.1017/ S0144686X1200116X

24. Bates MJ. The design of browsing and berrypicking techniques for the online search interface. Online Rev. 1989;13(5):407-24. https://doi.org/10. 1108/eb024320.

25. Barroso J, Gollop CJ, Sandelowski M, Meynell J, Pearce PF, Collins L. The challenges of searching for and retrieving qualitative studies. West J Nurs Res. 2003;25(2):153-78. https://doi.org/10.1177/0193945902250034.

26. Renz SM, Carrington JM, Badger TA. Two Strategies for qualitative content analysis: an Intramethod approach to triangulation. Qual Health Res. 2018; 28(5):824-31. https://doi.org/10.1177/1049732317753586.

27. Kalache A, Gatti A. Active ageing: A policy framework. Aging Male. 2002;5(1): 1-37. https://doi.org/10.1080/tam.5.1.1.37.

28. Group, T. H. E. W. Medicine : development of the World Health Organization WHOQOL-BREF quality of development of the World Health Organization WHOQOL-BREF quality of life assessment. cambridge.org, (September 2000); 2013. p. 551-8.

29. Sallis JF, Fisher EB, Owen N. Ecological models of Health behavior. In: Health Behavior and Health Education; 1990. p. 465-85.

30. Sallis JF, Cervero RB, Ascher W, Henderson KA, Kraft MK, Kerr J. An ecological approach to creating active living communities. Annu Rev Public Health. 2006;27(1):297-322. https://doi.org/10.1146/annurev.publhealth.27.021405. 102100

31. Salvo G, Lashewicz BM, Doyle-Baker PK, McCormack GR. Neighbourhood built environment influences on physical activity among adults: A systematized review of qualitative evidence. Int J Environ Res Public Health. 2018. https://doi.org/10.3390/ijerph15050897.

32. Scharlach AE, Lehning AJ, Scharlach AE. Ageing-friendly communities and social inclusion in the united ageing-friendly communities and social inclusion in the United States of America. cambridge.org, (2013); 2016. p. 110-36. https://doi.org/10.1017/S0144686X12000578. 
33. Barnett DW, Barnett A, Nathan A, Van Cauwenberg J, Cerin E. Built environmental correlates of older adults' total physical activity and walking: a systematic review and meta-analysis. Int J Behav Nutr Phys Act. 2017;14(1): 103. https://doi.org/10.1186/s12966-017-0558-z.

34. DE SOUZA LNN, DE CARVALHO PHB, Ferreira MEC. Quality of life and subjective well-being of physically active elderly people: A systematic review. J Phys Educ Sport. 2018;18(3):1615-23. https://doi.org/10.7752/jpes.2018.03237.

35. Rimmer JH. Use of the ICF in identifying factors that impact participation in physical activity/rehabilitation among people with disabilities. Disabil Rehabil. 2006;28(17):1087-95. https://doi.org/10.1080/09638280500493860.

36. Garcia MA, Angel JL, Angel RJ, Chiu C-T, Melvin J. Acculturation, gender, and active life expectancy in the Mexican-origin population. J Aging Health. 2015;27(7):1247-65. https://doi.org/10.1177/0898264315577880.

37. Mendoza-Núñez VM, Martínez-Maldonado Mde L, Correa-Muñoz E. Implementation of an active aging model in Mexico for prevention and control of chronic diseases in the elderly. BMC Geriatr. 2009;9(1):40. https:// doi.org/10.1186/1471-2318-9-40.

38. da Silva W, Barbosa K, de Oliveira F, de Brito F, de Lyra Ramos S, Fernandes $A$, et al. Personal and behavioral determinants of active aging. Int Arch Med. 2016;9(1).

39. Aird RL, Buys L. Active aging: Exploration into self-ratings of "being active," out-of-home physical activity, and participation among older australian adults living in four different settings. J Aging Res. 2015;2015. https://doi. org/10.1155/2015/501823.

40. Roberts E, Bishop A, Ruppert-Stroescu M, Clare G, Hermann J, Singh C, et al. Active aging for L.I.F.E. Topics Geriatric Rehabil. 2017;33(3):211-22. https:// doi.org/10.1097/TGR.0000000000000157

41. Xu J, Sorensen A, Hess P. A good place to age in place? Exploring the relationships between the built environment, Activity Participation and Healthy Aging. ProQuest Dissertations and Theses, vol. 188; 2018. Retrieved from https://tspace.library.utoronto.ca/handle/1807/89819

42. Filiatrault J, Bélanger E, Zunzunegui MV, Ahmed T, Yu H-T. An empirical comparison of different models of active aging in Canada: the international mobility in aging study. Gerontologist. 2015;gnv126. https://doi.org/10.1093/ geront/gnv126.

43. Cerin E, Nathan A, van Cauwenberg J, Barnett DW, Barnett A. The neighbourhood physical environment and active travel in older adults: A systematic review and meta-analysis. Int J Behav Nutr Phys Act. 2017. https://doi.org/10.1186/s12966-017-0471-5.

44. Plouffe L, Kalache A. Towards global age-friendly cities: determining urban features that promote active aging. J Urban Health. 2010;87(5):733-9. https://doi.org/10.1007/s11524-010-9466-0.

45. Ko P-C, Yeung W-JJ. An ecological framework for Active Aging in China. J Aging Health. 2018;30(10):1642-76. https://doi.org/10.1177/ 0898264318795564 .

46. Nyunt MSZ, Shuvo FK, Eng JY, Yap KB, Scherer S, Hee LM, et al. Objective and subjective measures of neighborhood environment (NE): relationships with transportation physical activity among older persons. Int J Behav Nutr Phys Act. 2015;12(1):108. https://doi.org/10.1186/s12966-015-0276-3.

47. Clarke P, George LK. The role of the built environment in the disablement process. Am J Public Health. 2005;95(11):1933-9. https://doi.org/10.2105/ AJPH.2004.054494.

48. Morris KS, McAuley E, Motl RW. Self-efficacy and environmental correlates of physical activity among older women and women with multiple sclerosis. Health Educ Res. 2008;23(4):744-52. https://doi.org/10.1093/her/cym067.

49. Saarloos D, Alfonso H, Giles-Corti B, Middleton N, Almeida OP. The built environment and depression in later life: the health in men study. Am J Geriatr Psych. 2011;19(5):461-70

50. Roelofsen P. Healthy ageing and the built environment. Int Buildings Int. 2014;6(1):3-10. https://doi.org/10.1080/17508975.2013.775097.

51. Quirk H, Crank H, Harrop D, Hock E, Copeland R. Understanding the experience of initiating community-based physical activity and social support by people with serious mental illness: a systematic review using a meta-ethnographic approach. System Rev. 2017;6(1):214. https://doi.org/10.1186/s13643-017-0596-2.

52. Rantanen T, Saajanaho M, Karavirta L, Siltanen S, Rantakokko M, Viljanen A, et al. Active aging - resilience and external support as modifiers of the disablement outcome: AGNES cohort study protocol. BMC Public Health. 2018;18(1):565. https://doi.org/10.1186/s12889-018-5487-5.

53. Kwok JYC, Ng KCH. User friendly living environmental research and Design for Older People. In: Designing inclusive futures. London: Springer London; 2008. p. 261-72. https://doi.org/10.1007/978-1-84800-211-1_25.
54. Yung EHK, Conejos S, Chan EHW. Social needs of the elderly and active aging in public open spaces in urban renewal. Cities. 2016;52:114-22. https://doi.org/10.1016/j.cities.2015.11.022.

55. WHO ,2007. (2010). WHO

56. Noguchi M, Ma N, Woo C, Chau H, Zhou J. The usability study of a proposed environmental experience design framework for active ageing. Buildings. 2018;8(12):167. https://doi.org/10.3390/buildings8120167.

57. Clarke P, Nieuwenhuijsen ER. Environments for healthy ageing: A critical review. Maturitas. 2009. https://doi.org/10.1016/j.maturitas.2009.07.011.

58. Swallow D, Cambridge H, Cinderby S, Attuyer K, Gilroy R, Bevan M, Croucher K. Co-designing urban living solutions to improve older People's mobility and well-being. J Urban Health. 2018;95(3):409-22. https://doi.org/10.1007/ s11524-018-0232-z.

59. Cunningham GO, Michael YL. Concepts guiding the study of the impact of the built environment on physical activity for older adults: A review of the literature. Am J Health Promot. 2004;18(6):435-43. https://doi.org/10.4278/ 0890-1171-18.6.435.

60. Temelová J, Dvořáková N. Residential satisfaction of elderly in the city Centre: the case of revitalizing neighbourhoods in Prague. Cities. 2012;29(5): 310-7. https://doi.org/10.1016/j.cities.2011.11.015.

61. Afacan Y. Elderly-friendly inclusive urban environments: learning from Ankara. Open House Int. 2013;38(1):52-63 Retrieved from http://search. ebscohost.com/login.aspx?direct=true\&profile=ehost\&scope=site\&authtype $=$ crawler\&jrnl=01682601\&asa $=Y \& A N=86195978 \& h=B 9 T 8 n j J T Q 5 a \% 2$ BYY8QK0pc\%2F\%2FbqGZDGRRkfVrWt3owQIMay4 IpquniYadTqSUsbdXAMaweZoGzN4w\%2FFhmsB9CylWA\%3D\%3D\&crl=c.

62. Elsawahli H, Shah Ali A, Ahmad F, Al-Obaidi KM. Evaluating potential environmental variables and active aging in older adults for age-friendly neighborhoods in Malaysia. J Hous Elder. 2017;31(1):74-92. https://doi.org/ 10.1080/02763893.2016.1268560.

63. Tiraphat S, Peltzer K, Thamma-Aphiphol K, Suthisukon K. The role of agefriendly environments on quality of life among thai older adults. Int J Environ Res Public Health. 2017;14(3). https://doi.org/10.3390/ ijerph14030282.

64. Sonmez Turel H, Malkoc Yigit E, Altug I. Evaluation of elderly people's requirements in public open spaces: A case study in Bornova District (Izmir, Turkey). Build Environ. 2007;42(5):2035-45. https://doi.org/10.1016/j.buildenv. 2006.03.004.

65. Aneshensel CS, Harig F, Wight RG. Aging, neighborhoods, and the built environment. In: Handbook of Aging and the Social Sciences. 8th ed; 2015. p. 315-35. https://doi.org/10.1016/B978-0-12-417235-7.00015-9.

66. Eisenberg $Y$, Vanderbom KA, Vasudevan V. Does the built environment moderate the relationship between having a disability and lower levels of physical activity? A systematic review. Prev Med. 2017;95:S75-84. https://doi. org/10.1016/j.ypmed.2016.07.019.

67. Karuppannan, S., Sivam, A., Koohsari, M., \& Sivam, A. (2012). Does urban design influence physical activity in the reduction of obesity? A review of evidence. Retrieved from http://search.ror.unisa.edu.au/record/UNISA_ ALMA51108480420001831/media/digital/open/9915909331601831/1214333 9180001831/13143337750001831/pdf

68. Hunter RH, Sykes K, Lowman SG, Duncan R, Satariano WA, Belza B. Environmental and policy change to support healthy aging. J Aging Soc Policy. 2011:23(4):354-71. https://doi.org/10.1080/08959420.2011.605642.

69. Lehne $\mathrm{G}$, Bolte $\mathrm{G}$. Equity impact of interventions to promote physical activity in older adults: protocol for a systematic review. Syst Rev. 2016;5(1): 17. https://doi.org/10.1186/s13643-016-0194-8.

70. Chrysikou E, Rabnett R, Tziraki C. Perspectives on the Role and Synergies of Architecture and Social and Built Environment in Enabling Active Healthy Aging. J Aging Res. 2016;2016:6189349. https://doi.org/10.1155/2016/6189349.

71. Keysor JJ, Jette AM, Lavalley MP, Lewis CE, Torner JC, Nevitt MC, Felson DT. Community environmental factors are associated with disability in older adults with functional limitations: the (MOST) study. J Gerontol A Biol Sci Med Sci. 2010;65(4):393-9. https://doi.org/10.1093/gerona/glp182.

72. Bauman A, Merom D, Bull FC, Buchner DM, Fiatarone Singh MA. Updating the Evidence for Physical Activity: Summative Reviews of the Epidemiological Evidence, Prevalence, and Interventions to Promote "Active Aging.". The Gerontologist. 2016;56(Suppl 2):S268-80. https://doi.org/10. 1093/geront/gnw031.

73. Santinha G, Costa C, Diogo S. How are local policies promoting older People's mobility? A case study. Urban Sci. 2018;2(3):63. https://doi.org/10. 3390/urbansci2030063. 
74. Li S-C, Lindenberger U, Hommel B, Aschersleben G, Prinz W, Baltes PB. Transformations in the couplings among intellectual abilities and constituent cognitive processes across the life span. Psychol Sci. 2004;15(3): 155-63. https://doi.org/10.1111/j.0956-7976.2004.01503003.x.

75. Michael YL, Green MK, Farquhar SA. Neighborhood design and active aging Health Place. 2006;12(4):734-40. https://doi.org/10.1016/J.HEALTHPLACE. 2005.08.002

76. Koohsari MJ, Mavoa S, Villanueva K, Sugiyama T, Badland H, Kaczynski AT, Owen N, Giles-Corti B. Public open space, physical activity, urban design and public health: concepts, methods and research agenda. Health Place. 2015;33:75-82. https://doi.org/10.1016/j.healthplace.2015.02.009.

77. Nagel CL, Carlson NE, Bosworth M, Michael YL. The relation between neighborhood built environment and walking activity among older adults. Am J Epidemiol. 2008;168(4):461-8. https://doi.org/10.1093/aje/kwn158.

78. Clarke P, Ailshire JA, Lantz P. Urban built environments and trajectories of mobility disability: findings from a national sample of community-dwelling American adults (1986-2001). Soc Sci Med. 2009;69(6):964-70. https://doi. org/10.1016/j.socscimed.2009.06.041.

79. Labus A. Concepts of urban renewal in an aging society in the XXI centurycase studies in the polish cities; 2013.

80. Fadda G, Cortés A, Olivi A, Tovar M. The perception of the values of urban space by senior citizens of Valparaiso. J Aging Stud. 2010;24(4):344-57. https://doi.org/10.1016/j.jaging.2010.07.001.

81. Clarke P, Gallagher NA. Optimizing mobility in later life: the role of the urban built environment for older adults aging in place. J Urban Health. 2013;90(6):997-1009. https://doi.org/10.1007/s11524-013-9800-4.

82. Van Cauwenberg J, Van Holle V, De Bourdeaudhuij I, Van Dyck D, Deforche B. Neighborhood walkability and health outcomes among older adults: the mediating role of physical activity. Health Place. 2016;37:16-25. https://doi. org/10.1016/j.healthplace.2015.11.003.

83. Andersson JE. Architecture for the silver generation: exploring the meaning of appropriate space for ageing in a Swedish municipality. Health Place. 2011;17(2):572-87. https://doi.org/10.1016/j.healthplace.2010.12.015.

84. Kerr J, Rosenberg D, Frank L. The role of the built environment in healthy aging. J Plan Lit. 2012;27(1):43-60. https://doi.org/10.1177/ 0885412211415283.

85. Borst HC, Graham JMA, van Dongen JEF, Miedema HME, de Vries SI, Bakker I. Influence of environmental street characteristics on walking route choice of elderly people. J Environ Psychol. 2009;29(4):477-84. https://doi.org/10. 1016/j.jenvp.2009.08.002

86. Chan AC-M, Cao T. Age-friendly Neighbourhoods as civic participation: implementation of an active ageing policy in Hong Kong. J Soc Work Pract. 2015;29(1):53-68. https://doi.org/10.1080/02650533.2014.993947.

87. Sugiyama T, Thompson CW. Outdoor environments, activity and the wellbeing of older people: Conceptualising environmental support. Environ Plan A. 2007;39(8):1943-60. https://doi.org/10.1068/a38226.

88. Woo J, Chan R, Leung J, Wong M. Relative contributions of geographic, socioeconomic, and lifestyle factors to quality of life, frailty, and mortality in elderly. PLoS One. 2010;5(1):e8775. https://doi.org/10.1371/journal.pone. 0008775.

89. Li F, Fisher KJ, Brownson RC, Bosworth M. Multilevel modelling of built environment characteristics related to neighbourhood walking activity in older adults. J Epidemiol Community Health. 2005. https://doi.org/10.1136/ jech.2004.028399.

90. Veitch J, De Bourdeaudhuij I, Ghekiere A, Van Dyck D, Clarys P, Van Hecke L, et al. Park characteristics preferred for adolescent park visitation and physical activity: A choice-based conjoint analysis using manipulated photographs. Landsc Urban Plan. 2018;178:144-55. https://doi.org/10.1016/j. landurbplan.2018.05.017.

91. SteelSteels S. Key characteristics of age-friendly cities and communities: A review. Cities. 2015;47:45-52. https://doi.org/10.1016/j.cities.2015.02.004s, S. (2015). Key characteristics of age-friendly cities and communities: A review. Cities. https://doi.org/10.1016/j.cities.2015.02.004.

92. Rioux $\mathrm{L}$, Werner $\mathrm{C}$. Residential satisfaction among aging people living in place. J Environ Psychol. 2011;31(2):158-69. https://doi.org/10.1016/j.jenvp.2010.12.001.

93. Garin N, Olaya B, Miret M, Ayuso-Mateos JL, Power M, Bucciarelli P, Haro JM. Built environment and elderly population Health: A comprehensive literature review. Clin Pract Epidemiol Ment Health. 2014;10(1):103-15. https://doi.org/10.2174/1745017901410010103.

94. Takano T, Nakamura K, Watanabe M. Urban residential environments and senior citizens' longevity in megacity areas: the importance of walkable green spaces. J Epidemiol Community Health. 2002;56(12):913-8. https://doi. org/10.1136/jech.56.12.913.

95. Gill T, Taylor AW, Pengelly A. A population-based survey of factors relating to the prevalence of falls in older people. Gerontology. 2005;51(5):340-5.

96. Malhotra R, Chan A, Malhotra C, Østbye T. Prevalence, awareness, treatment and control of hypertension in the elderly population of Singapore. Hypertens Res. 2010;33(12):1223-31. https://doi.org/10.1038/hr.2010.177.

97. Mishra V. Effect of indoor air pollution from biomass combustion on prevalence of asthma in the elderly. Environ Health Perspect. 2003;111(1): 71-8 Retrieved from https://www.ncbi.nlm.nih.gov/pmc/articles/PMC1241308/.

98. Mendoza-Ruvalcaba NM, Fernández-Ballesteros R. Effectiveness of the vital aging program to promote active aging in Mexican older adults. Clin Interv Aging. 2016;11:1631-44. https://doi.org/10.2147/CIA.S102930.

99. Mokaberian M, Kashani V, Kashani K, Somaye NT. Comparison of the happiness of active and passive elderly women and men in Tehran. Growth Mobility J. 2014;6(2):183-94. https://doi.org/10.22059/JMLM.2014.50456.

100. Yur'yev A, Leppik L, Tooding L-M, Sisask M, Värnik P, Wu J, Värnik A. Social inclusion affects elderly suicide mortality. Int Psychogeriatr. 2010;22(08): 1337-43. https://doi.org/10.1017/S1041610210001614.

101. Mendes FR. Active ageing: A right or a duty? Health Sociol Rev. 2013;22(2): 174-85. https://doi.org/10.5172/hesr.2013.22.2.174.

102. Vandenbroucke, F. (2012). Social justice and individual ethics in an open society: Equality, responsibility, and incentives. Retrieved from https://books. google.com/books?hl=en\&lr=\&id=EiXwCAAAQBAJ\&oi=fnd\&pg=PR7\&dq= Social+justice+and+individual+ethics+in+an+open+society\&ots=DrHncyOI2 x\&sig=M7IVenl5HW1ntTznORW_rSBotg

103. Hanson E, Magnusson L, Arvidsson H, Claesson A, Keady J, Nolan M. Working together with persons with early stage dementia and their family members to design a user-friendly technology-based support service. Dementia. 2007;6(3):411-34. https://doi.org/10.1177/1471301207081572.

104. McGarry P, Morris J. A great place to grow older: a case study of how Manchester is developing an age-friendly city. Working Older People. 2011; 15(1):38-46. https://doi.org/10.5042/wwop.2011.0119.

105. Zeitler E, Buys L, Aird R, Miller E. Mobility and active ageing in suburban environments: Findings from in-depth interviews and person-based GPS tracking. Curr Gerontol Geriatr Res. 2012;2012. https://doi.org/10.1155/2012/257186.

106. Del Barrio E, Marsillas S, Buffel T, Smetcoren A-S, Sancho M. From active aging to active citizenship: the role of (age) friendliness. Soc Sci. 2018;7(8): 134. https://doi.org/10.3390/socsci7080134.

107. Galea S, Freudenberg N, Vlahov D. Cities and population health. Soc Sci Med. 2005;60(5):1017-33. https://doi.org/10.1016/J.SOCSCIMED.2004.06.036.

108. Alpay LL, Toussaint PJ, Ezendam NPM, Rövekamp TAJM, Graafmans WC, Westendorp RGJ. Easing internet access of health information for elderly users. Health Inform J. 2004;10(3):185-94. https://doi.org/10.1177/ 1460458204045416

109. Masotti PJ, Fick R, Johnson-Masotti A, MacLeod S. Healthy naturally occurring retirement communities: A low-cost approach to facilitating healthy aging. Am J Public Health. 2006;96(7):1164-70. https://doi.org/10. 2105/AJPH.2005.068262.

110. Paganini-Hill A. Aging in place in a retirement community: $90+$ year olds. J Hous Elder. 2013;27(1-2):191-205. https://doi.org/10.1080/02763893.2012.754822.

111. Tam M. A model of active ageing through elder learning: the elder academy network in Hong Kong. Educ Gerontol. 2013;39(4):250-8. https:// doi.org/10.1080/03601277.2013.750931.

112. Taraghi Z, llali ES. A comparison of older adults' and managers' attitudes towards age-Friendly City indexes. Salmand. 2018:236-49. https://doi.org/10. 32598/sija.13.2.236.

113. Levasseur M, Dubois MF, Généreux M, Menec $V$, Raina P, Roy M, et al. Capturing how age-friendly communities foster positive health, social participation and health equity: A study protocol of key components and processes that promote population health in aging Canadians. BMC Public Health. 2017;17(1). https://doi.org/10.1186/s12889-017-4392-7.

114. Lui C-W, Everingham J-A, Warburton J, Cuthill M, Bartlett H. What makes a community age-friendly: A review of international literature. Aust Journal Ageing. 2009;28(3):116-21. https://doi.org/10.1111/j.1741-6612.2009.00355.x.

115. Temelová J, Slezáková A. The changing environment and neighbourhood satisfaction in socialist high-rise panel housing estates: the timecomparative perceptions of elderly residents in Prague. Cities. 2014;37:8291. https://doi.org/10.1016/j.cities.2013.12.002.

116. Tzoulas K, Kaźmierczak A, James P, Korpela K, Venn S, Yli-Pelkonen V, Niemela J. Promoting ecosystem and human health in urban areas using 
Green infrastructure: A literature review. Landsc Urban Plan. 2007;81 (3):16778. https://doi.org/10.1016/j.landurbplan.2007.02.001.

117. Alidoust S, Bosman C. Planning for an ageing population: links between social health, neighbourhood environment and the elderly. Australian Planner. 2015;52(3):177-86. https://doi.org/10.1080/07293682.2015.1034145.

118. Oswald, F., Health, H. W. environmental, \& 2004, U. (n.d.). fo_housinghealthwahl2004.pdf. psychologie.uni-heidelberg.de. Retrieved from https://www. psychologie.uni-heidelberg.de/ae/apa/pdf/literatur/fo_housinghealth.pdf

119. Stokols D. Establishing and maintaining health environment: toward a social ecology of health promotion. Am Psychol. 1992;47(6):22.

120. Grad FP. The preamble of the constitution of the World Health Organization. Bull World Health Organ. 2002;80(July 1946):981-2.

121. Council, N. R. New Directions in the Sociology of Aging. Washington, D.C.: National Academies Press; 2013. https://doi.org/10.17226/18508.

122. Wiles JL, Allen RES, Palmer AJ, Hayman KJ, Keeling S, Kerse N. Older people and their social spaces: A study of well-being and attachment to place in Aotearoa New Zealand. Soc Sci Med. 2009;68(4):664-71. https://doi.org/10. 1016/J.SOCSCIMED.2008.11.030

123. Adams MA, Ryan S, Kerr J, Sallis JF, Patrick K, Frank LD, Norman GJ. Validation of the neighborhood environment walkability scale (NEWS) items using geographic information systems. J Phys Act Health. 2009;6(s1):S11323. https://doi.org/10.1123/jpah.6.51.s113.

124. Phillipson, C. (2012). Developing age-friendly cities: policy challenges \&amp; options. Retrieved from http://www.bjf.org.uk/web/documents/page/ HLINViewpoint37AgeFriendlyCities.pdf

125. Barbosa C, Feio P, Fernandes A, Thorslund M. Governance strategies to an ageing society - local roll in multi level processes. J Comp Polit. 2016;9(1):4-18.

126. Menec VH, Means R, Keating N, Parkhurst G, Eales J. Conceptualizing agefriendly communities. Can J Aging. 2011;30(03):479-93. https://doi.org/10. 1017/S0714980811000237.

127. Paúl C, Ribeiro O, Teixeira L. Active ageing: an empirical approach to the WHO model. Curr Gerontol Geriatr Res. 2012;2012. https://doi.org/10.1155/ 2012/382972

128. Bronfenbrenner $U$. Toward an experimental ecology of human development. Am Psychol. 2006;32(7):513-31. https://doi.org/10.1037/0003066x.32.7.513.

129. Torres S. A culturally-relevant theoretical framework for the study of successful ageing. Ageing Soc. 1999;19(1):33-51. https://doi.org/10.1017/ S0144686X99007242.

130. Oswald F, Jopp D, Rott C, Wahl HW. Is aging in place a resource for or risk to life satisfaction? Gerontologist. 2011;51(2):238-50. https://doi.org/10.1093/ geront/gnq096.

131. Wiederhold BK, Riva G, Graffigna G. Ensuring the best Care for our Increasing Aging Population: Health engagement and positive technology can help patients achieve a more active role in future healthcare. Cyberpsychol Behav Soc Netw. 2013;16(6):411-2. https://doi.org/10.1089/ cyber.2013.1520.

132. Lak A, Aghamolaei R, Baradaran HR, Myint PK. Development and validation of elder-friendly urban spaces questionnaire (efusq). BMC Geriatr. 2019;19(1). https://doi.org/10.1186/s1 2877-019-1355-0

133. Adams MA, Sallis JF, Conway TL, Frank LD, Saelens BE, Kerr J, et al. Neighborhood environment profiles for physical activity among older adults. Am J Health Behav. 2012;36(6):757-69. https://doi.org/10.5993/AJHB. 36.6.4.

\section{Publisher's Note}

Springer Nature remains neutral with regard to jurisdictional claims in published maps and institutional affiliations.

Ready to submit your research? Choose BMC and benefit from:

- fast, convenient online submission

- thorough peer review by experienced researchers in your field

- rapid publication on acceptance

- support for research data, including large and complex data types

- gold Open Access which fosters wider collaboration and increased citations

- maximum visibility for your research: over $100 \mathrm{M}$ website views per year

At BMC, research is always in progress.

Learn more biomedcentral.com/submissions 